THESIS

\title{
THE INFLUENCE OF CHILLING REQUIREMENT ON THE SOUTHERN DISTRIBUTION LIMIT OF EXOTIC RUSSIAN OLIVE (ELAEAGNUS ANGUSTIFOLIA) IN WESTERN NORTH AMERICA
}

\author{
Submitted by \\ Kimberly R. Guilbault \\ Graduate Degree Program in Ecology
}

In partial fulfillment of the requirements

For the Degree of Master of Science

Colorado State University

Fort Collins, Colorado

Spring 2011

Master's Committee:

Advisor: Cynthia Brown

Jonathan Friedman

Patrick Shafroth

Amy Angert 


\begin{abstract}
THE INFLUENCE OF CHILLING REQUIREMENT ON THE SOUTHERN DISTRIBUTION LIMIT OF EXOTIC RUSSIAN OLIVE (ELAEAGNUS ANGUSTIFOLIA) IN WESTERN NORTH AMERICA
\end{abstract}

Russian olive (Elaeagnus angustifolia L.), a Eurasian tree, is now a dominant species along rivers in western North America. The southern boundary of Russian olive distribution in western North America runs through southern California, Arizona, New Mexico and Texas. I related the distributional pattern of Russian olive to temperature regime and investigated potential temperature-dependent mechanisms that might explain this distributional limit. Specifically, I investigated whether lack of cold temperatures at the southern limit may prevent the accumulation of sufficient chilling and inhibit dormancy loss of seeds and buds, potentially constraining Russian olive's southern distribution boundary.

First, I used field observations to thoroughly define the southern limit of Russian olive across western USA and related this distribution to temperature variables. I found that Russian olive occurrence was more strongly associated with low winter temperatures than with excessive summer heat. I then carried out controlled seed germination and vegetative bud-break experiments and a field survey of fruit production and seed viability. 
Next, I cold stratified Russian olive seeds in growth chambers with temperature regimes simulating six locations along a latitudinal gradient from Socorro, New Mexico $\left(33.8^{\circ} \mathrm{N}\right.$ latitude) to Presidio, Texas $\left(29.56^{\circ} \mathrm{N}\right.$ latitude). Both germination proportion and germination times were highest under temperature regimes simulating locations near the southern range limit and declined for temperature regimes simulating locations north and south of the range limit. This pattern only weakly supports the hypothesis that germination would decrease south of the southern range limit. I then conducted an additional controlled germination experiment containing treatments with varying levels of cold stratification, the results of which suggest that the chilling requirement for germination is partly responsible for the southern range limit. Both seed germination proportion and germination time decreased when the amount of cold stratification dropped below values typical of the southern range limit.

I also carried out a preliminary bud-break experiment where Russian olive cuttings that were pre-exposed to natural chilling were subjected to various levels of additional chilling in a refrigerator. The results of this experiment suggest that a high percentage of buds burst with chilling values less than those typical of the southern limit. I then conducted a controlled budbreak experiment with cuttings that accumulated varying levels of chilling naturally. Percent bud break decreased when chilling dropped below values typical of the southern range limit, suggesting that the chilling requirement for bud-break is partly responsible for the southern range limit. In $17-65 \%$ of the years from $1980-2000$, the chilling accumulated at a site near the southern range limit (El Paso, Texas) would lead to a $10 \%$ or more decrease in bud-break. The potential decline in growth could have large fitness consequences for Russian olive trees. Finally, I collected fruit production and seed viability data. While fruit production did not decline towards the southern range limit, seed viability declined with decreasing latitude. 
If climate change follows a warming trend, it is very likely that the chilling requirement for bud-break of Russian olive trees will not be met in some years and this combined with decreased seed viability at lower latitudes may cause its southern range limit to retreat northward. The retreat of a widespread non-native species, such as Russian olive, may present land managers and ecologists with a unique restoration opportunity. 


\section{ACKNOWLEDGEMENTS}

I would like to thank Tom Bates for collection of the Russian olive distribution data and Joanne Saher for analysis of the Russian olive distribution data. I would also like to thank Hannah Wilbur, Cynthia Pritekel, James Bromberg, Chrissy Alba-Lynn, Kristen Kascinski, Jess Salo and Patty York for field and greenhouse help. Furthermore, I would like to thank my committee members Cynthia Brown, Jonathan Friedman, Patrick Shafroth, and Amy Angert for all of their feedback and support. Funding for this work was generously provided by the U.S. Geological Survey, Invasive Species and Global Change Programs. 


\section{TABLE OF CONTENTS}

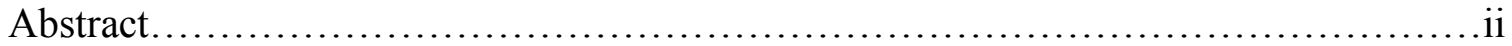

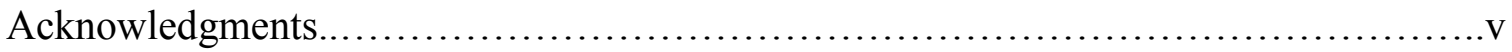

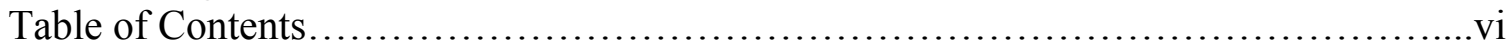

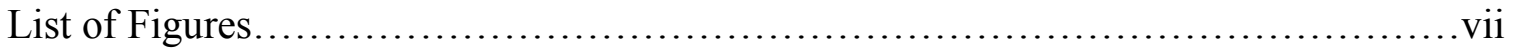

List of Tables........................................................................

CHAPTER I

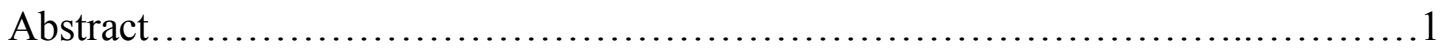

CHAPTER II

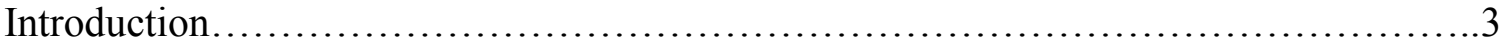

CHAPTER III

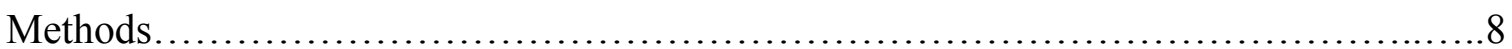

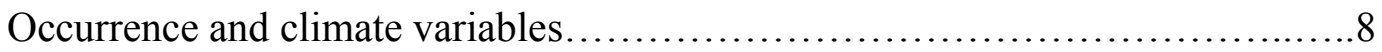

Germination and stratification thermal time units...........................................

Chill units and bud-break...................................................12

CHAPTER IV

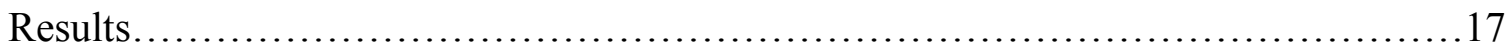

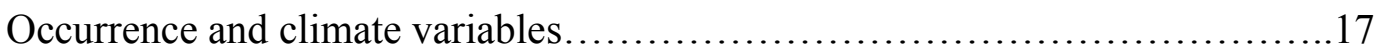

Germination and stratification thermal time units..............................18

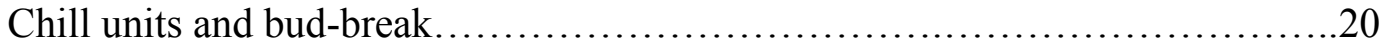

CHAPTER V

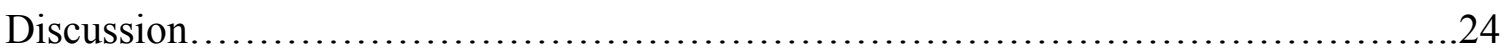

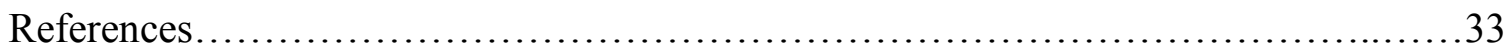

Appendix A: Expanded Methods......................................................

Appendix B: Additional Tables.................................................. 43

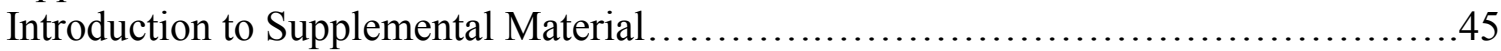

Appendix C: Preliminary germination experiment, 2009-2010 .......................46

Appendix D: Preliminary bud-break experiment, 2009-2010_.......................58

Appendix E: Vegetative and flowering growth and fruit development...................60

Appendix F: Fruit production and seed viability along a latitudinal gradient.............64

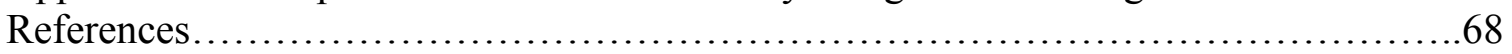




\section{LIST OF FIGURES}

Figure 1. Locations of planted and naturally occurring Russian olive in relation to mean

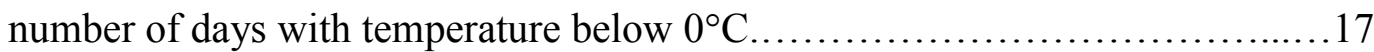

Figure 2. Proportion of Russian olive seeds germinated as a function of stratification thermal time units (degree days below $15^{\circ} \mathrm{C}$ )................................. 19

Figure 3. Mean germination time (MGT), in days, of Russian olive seeds as a function of stratification thermal time units (degree days below $15^{\circ} \mathrm{C}$ ) .....................20

Figure 4. Probability of Russian olive bud-break as a function of Chill Units for observed and predicted values. .................................................. 21

Figure 5. Mean Time until Bud-break (MTB), in days, as a function of Chilling Units...22

Figure $\mathrm{C} 1$. Proportion of Russian olive seeds germinated as a function of stratification

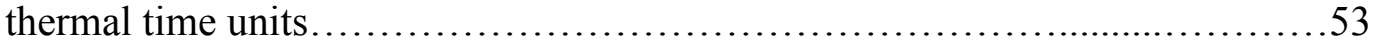

Figure D1. Proportion Russian olive bud-break as a function of Chill Units..............59

Figure E1. Schematic of Russian olive tree...................................60 


\section{LIST OF TABLES}

Table 1. Log pseudolikelihood and pseudo $\mathrm{r}^{2}$ generated by univariate logistic regression models predicting the occurrence of planted and naturally occurring Russian olive................................................................... 18

Table 2. Maximum likelihood and odds-ratio estimates by bud source for bud-break as a function of chill units.

Table B1. Treatments with corresponding stratification thermal time units $\left(\mathrm{S}_{\mathrm{tt}}\right.$ units -

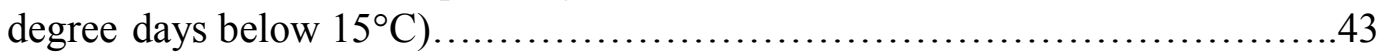

Table B2. Stratification thermal time units and proportion of Russian olive seeds

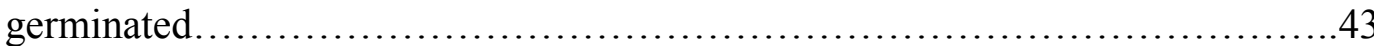

Table B3. Mean time until bud-break (MTB) by bud source and chill unit treatment.....44

Table C1. Stratification treatment and corresponding latitudes......................47

Table C2. Maximum and minimum temperatures and day length for the months of October-May for both the South and North regimes. .........................51

Table C3. Stratification treatment and proportion of Russian olive seeds germinated......................................................... 54

Table E1. Flowering potential and fruit development of sexually mature Russian olive trees $(n=10)$ in Fort Collins, CO in June 2009 


\section{CHAPTER I: ABSTRACT}

Russian olive (Elaeagnus angustifolia L.), a Eurasian tree that is now a dominant species along rivers in western North America, has an apparent southern boundary running through southern California, Arizona, New Mexico and Texas. I used field observations to thoroughly define the southern limit of Russian olive across western USA and related this distribution to temperature variables. I then related the distributional pattern of Russian olive to temperature regime and investigated potential temperaturedependent mechanisms that might explain this distributional limit. Specifically, I investigated whether lack of cold temperatures at the southern limit may prevent the accumulation of sufficient chilling and inhibit dormancy loss of seeds and buds, potentially constraining its southern distribution boundary.

I found that Russian olive occurrence was more strongly associated with low winter chill than with excessive summer heat and results of controlled seed germination and vegetative bud-break experiments suggest that the chilling requirement for germination and bud-break are partly responsible for the southern range limit. Both seed germination proportion and germination time decreased under conditions simulating those south of the southern range limit. Similarly, percentage bud break decreased when chilling dropped below values typical of the southern range limit. In $17-65 \%$ of the years from 1980-2000, the chilling accumulated at a site near the southern range limit (El Paso, TX) would lead to a $10 \%$ or more decrease in bud-break. The potential decline in growth could have large fitness consequences for Russian olive trees. 
If climate change follows a warming trend, my results suggest that the chilling requirement for bud-break of Russian olive trees will not be met in some years and its southern range limit may retreat northward. The retreat of a widespread non-native species, such as Russian olive, may present land managers and ecologists with a restoration opportunity. This information can also inform models predicting the potential distribution of Russian olive in response to climate change. 


\section{CHAPTER II: INTRODUCTION}

Understanding the factors that constrain species' ranges has long been a focus of ecological research (e.g., Darwin 1859; MacArthur 1972), and this line of investigation is currently important because of concern over the spread of non-native species (Vitousek et al. 1996) and strong interest in predicting changes in distributions in response to climate change (Kriticos et al. 2003; Morin et al. 2008; Bradley 2009). Temperature and precipitation (i.e. climate) can limit non-native plant distributions at global and regional scales (Guisan and Zimmermann 2000; Pearson and Dawson 2003; Thuiller et al. 2005). If climate follows the prevailing warming trend (IPCC 2007), continued rising temperatures could contribute to expansion of non-native species with limited cold and frost tolerance (Kriticos et al. 2003; Jarnevich and Stohlgren 2009). Alternatively, warming could contribute to contraction of non-native species that require cold temperatures for increased seed production, seedling emergence, seedling establishment (Williams et al. 2007) or improved vegetative growth and flowering (Bradley et al. 2009; Dogramaci et al. 2010).

Management decisions relating to climate change often rely on models that predict suitable or unsuitable habitat under various climate scenarios (Bradley and Wilcove 2009). Knowledge of the current climatic constraints on a population's distribution can help parameterize these models and make predictions more accurate. At southern range limits in the northern hemisphere, distributions of species are likely to 
contract or fragment (Shafer 2001; Morin et al. 2008), which may present unique restoration opportunities for resource managers. Knowing regions of potential retreat may help managers prioritize modeling and experimental studies investigating which species would be best to introduce to these 'novel' habitats (Bradley and Wilcove 2009).

The life cycle events of temperate trees, such as germination and bud-break, are often regulated by the physiological linkage between temperature and dormancy (Rallo and Martin 1991; Chuine and Beaubien 2001; Morin et al. 2007; Bonner 2008). Dormancy prevents seeds from germinating and buds from opening in the autumn or winter when favorable conditions for growth and survival are not sustained for more than a few days at a time (Bonner 2008). Temperate tree species primarily exhibit embryonic seed dormancy (Baskin and Baskin 2004). Seeds generally require a period of moist chilling (cold stratification), ideally between 3 and $6^{\circ} \mathrm{C}$, (Bouweester and Karssen 1992; Batlla et al. 2009; Scholten 2009)—although limited dormancy release may still occur at temperatures up to $15^{\circ} \mathrm{C}$ (Batlla et al. 2009; Stokes 1965)—followed by warm incubation to overcome this dormancy (Bonner 2008). Similarly, after bud formation, the vegetative and flower buds of many temperate trees enter a physiological dormancy, and require a period of cold temperature (chilling), ideally between 0 and $7^{\circ} \mathrm{C}$, to break dormancy (Richardson et al. 1974; Cesaraccio et al. 2004). Buds remain in a state of quiescence after this cold period until a sufficient accumulation of warm temperatures (forcing) encourages cell expansion and growth (Perry 1971; Richardson et al. 1974; Cesaraccio et al. 2004). In western North America, chilling is decreasing with warming trends (Baldocchi and Wong 2008; Luedeling et al. 2009), and insufficient chill to break bud dormancy is a common problem for non-native commercial nut and fruit trees in western 
North America (Baldocchi and Wong 2008). At southern range limits, insufficient chilling may inhibit dormancy loss and hinder both flower development (Prentice and Helmisaair 1991) and germination (Batlla et al. 2009). Chilling requirements have been found to determine range limits in both present (Fang and Lechowicz 2006; Morin et al. 2007; Morin et al. 2009) and future climate scenarios (Sykes et al. 1996; Shafer et al. 2001; Morin et al. 2009).

Russian olive (Elaeagnus angustifolia L.) is a small deciduous, insect pollinated tree native to southern Europe and Asia that was first introduced to North America around 1900 (Katz and Shafroth 2003). Fruits are 1-1.5 cm long, containing a single large seed, and are dispersed by vertebrates and flowing water (Katz and Shafroth 2003). Russian olive is now one of the dominant woody plants along rivers in western North America and has become naturalized in all of the western United States (Katz and Shafroth 2003; Friedman et al. 2005). Where Russian olive is present, it often outcompetes native pioneer riparian species, such as cottonwood and willow (Pearce and Smith 2001), and it is considered a noxious weed in most of the western states.

Consequently, Russian olive is the focus of substantial control and associated restoration efforts throughout western North America (Shafroth et al. 2010). Understanding what factors limit Russian olive at its southern distribution can help inform management efforts that may rely on predicting the response of Russian olive to climate change and determining future suitable locations for Russian olive.

Climate variables have been used to model Russian olive presence and predicted occurrence in its non-native, North American range (Peterson et al. 2003; Jarnevich and Reynolds 2010). Additionally, presence and absence data from 475 sites in the 17 
western states in Friedman et al. (2005) reveal a southern boundary to Russian olive distribution in western North America running through southern California, Arizona and Texas. Furthermore, in the western USA the frequency of occurrence of Russian olive decreases with increasing mean annual minimum temperature (Friedman et al. 2005). If the Russian olive distribution is in equilibrium with climate, then relations between Russian olive occurrence and climate can be used to predict site susceptibility to invasion.

Russian olive was cultivated in many places in New Mexico early in the twentieth century (Wooton and Standley 1915). By the 1960s, it was abundant along the Rio Grande and had already reached the current southern limit of its distribution, in El Paso, Texas (Campbell and Dick-Peddie 1964). The fact that the southern limit of Russian olive along the Rio Grande has been stable for at least 47 years suggests that this limit is set by environmental factors, possibly including climate. Insufficient chilling could limit southward spread of Russian olive through incomplete dormancy loss of seeds and buds. Russian olive seeds generally exhibit embryonic dormancy and require a period of cold stratification for germination (Hogue and LaCroix 1970; Olson 1974; Hamilton and Carpenter 1976). Field observations indicated that both vegetative and flower bud-break occurred near the southern limit in 2009 (Guilbault, personal observation). However, productivity could decline towards the southern range limit in some years, reducing the ability of Russian olive to regenerate and maintain populations in the long-term.

I used field observations to more precisely define the southern limit of Russian olive in western USA and relate this distribution to temperature variables. I hypothesized that (1) low temperature variables would be the best predictors of Russian olive presence 
near the southern range limit. Additionally, I used controlled experiments to investigate the chilling requirement of Russian olive seeds and buds, potential mechanisms determining the southern range limit. I hypothesized that (2) percent germination would decrease with stratification levels below those typical of locations near the southern range limit and that (3) percent bud break would decrease for chilling levels below those typical of locations near the southern range limit. 


\section{CHAPTER III: METHODS}

\section{Occurrence and climate variables}

I carried out an intensive survey of the occurrence of Russian olive at its southern range limit. A vehicle-mounted global positioning system recorded my observations of Russian olive along roads in southern California, Nevada, Arizona, New Mexico and Texas. Using ArcGIS 9.2 (Environmental Systems Research Institute, Redlands, CA, USA) I overlaid the track log from this expedition on the PRISM climate data set (acquired from the Climate Source) to identify pixels $(2 \mathrm{~km} \mathrm{x} 2 \mathrm{~km})$ containing planted Russian olive ( $\mathrm{n}=200)$, naturally occurring Russian olive ( $\mathrm{n}=123)$, or no Russian olive $(n=5688)$.

I used logistic regression (Stata v. 10, StataCorp, College Station, TX) to relate occurrence of Russian olive in pixels to various climate parameters in the PRISM data set (Table 4) and to distance from mapped water in a base water layer (Environmental Systems Research Institute, Redlands, CA). Climate variables were annual means for 1961-1990, except for growing degree-days, which was for 1951-1980. To account for variation in search effort among pixels, I weighted observations by the length of road searched within the pixel divided by pixel area.

Germination and stratification thermal time units

Because my intensive survey revealed that low winter temperatures were associated with the occurrence of Russian olive, I carried out a greenhouse experiment 
to examine the relationship between cold stratification and seed germination near in temperatures characteristic of areas north and south of the range limit. Because the daily mean temperatures in this latitudinal range are generally not below $0^{\circ} \mathrm{C}$, I quantified stratification using a linear thermal-time model described in Pritchard et al. (1996) and Handley and Davy (2005) (Appendix A). Stratification thermal time units ( $\mathrm{S}_{\mathrm{tt}}$ units), in units of degree days, were calculated by summing the daily difference between the mean daily temperature and a ceiling threshold temperature above which dormancy release generally does not occur (set at $15^{\circ} \mathrm{C}$ ). To determine the number of stratification thermal time units naturally occurring at the approximate southern range limit, I used daily maximum and minimum temperature data for the months of October through May from 1980-2003 (Daymet U.S. Data Center www.daymet.org) at $31.8^{\circ} \mathrm{N}, 106.4^{\circ} \mathrm{W}$. I then estimated hourly temperature values from these daily maximum and minimum values as described in Linvill (1990) (Appendix A) to calculate a daily mean. For the years 19802000 , an average of $948 S_{t t}$ units occurred at the southern range limit. The accumulated amount of chilling (948 $\mathrm{S}_{\mathrm{tt}}$ units) calculated using the linear thermal time unit model above was very similar to the value (958 Chill units) calculated by a more complicated curvilinear model of bud response to temperature (see below). The response to temperature is very similar for seeds and buds (Seeley and Damavandy 1985); therefore, the linear thermal time model appears to be effective for estimating seed response to temperature. My experiment included 13 temperature treatments with $S_{t t}$ units representative of locations near and south of the southern range limit $(0,52,138,233$, $328,423,518,613,708,804,899,985$ and $1080 \mathrm{~S}_{\mathrm{tt}}$ units). 
I collected fruit from healthy, naturalized Russian olive populations at two locations (Las Cruces, New Mexico and Socorro, New Mexico) in early September 2009. At the Socorro location $\left(34.06^{\circ} \mathrm{N}\right)$, where stands of Russian olive trees were more common, I collected fruit from three sites to average out local variability. In Las Cruces $\left(32.30^{\circ} \mathrm{N}\right)$, where I found only one stand of naturalized Russian olive trees along the river channel, I collected fruit from only one site. I collected fruit from at least 15 trees at each location, assigned each tree a unique tree number and population identifier, and kept seed separate for each tree.

I then hand-cleaned the fruit from 15 trees for each location and placed seeds in moist sand, $1.5 \mathrm{~cm}$ below the surface, in $25.4 \mathrm{~cm}$ by $25.4 \mathrm{~cm}$ trays divided into $60 \mathrm{cells}$ (one seed per cell). I randomly assigned seeds to cells and distributed seeds from each tree equally among treatments and subsamples to control for inter- and intra-population variability. Each tray received 60 seeds total and 30 seeds from each location (Socorro, Las Cruces). For each location, 15 seeds were scarified and 15 were not scarified. To scarify (soften and/or break the hard seed coat), I soaked seeds for 40 minutes in $98 \%$ concentrated sulfuric acid (Heit 1967).

Unlike previous studies of Russian olive germination that stratified seeds at a constant temperature (Hogue and LaCroix 1970), I exposed seeds to temperatures that fluctuated diurnally to better represent natural conditions (Bonner 2008). Temperature treatments were applied in two identical growth units (approximate: height $\mathrm{x}$ width $\mathrm{x}$ depth $208 \times 208 \times 253 \mathrm{~cm})$. We used the same daily temperature regime throughout the experiment, based on a sine curve with a minimum of $-2.3^{\circ} \mathrm{C}$ and a maximum of $15^{\circ} \mathrm{C}$. The regime was determined using the following equation: $(\max +\min / 2+(\max -\min ) / 2 *$ 
$\operatorname{SIN}\left(2 \pi^{*}(t-9) / 24\right)$ where $t=$ hour in military time and " 9 " sets the phase so that the maximum is at $3 \mathrm{pm}$ and the minimum at $3 \mathrm{am}$. The curve was then truncated based upon the minimum temperature limit of the growth units at $0^{\circ} \mathrm{C}\left(8.29 \mathrm{~S}_{\mathrm{tt}}\right.$ units per day). All trays started in one of the growth units and were then removed at various intervals throughout the experiment. At each interval a different number of $S_{t t}$ units had accumulated, representing one of the 13 treatments above. Each treatment had six trays and three trays were placed in each chamber. Trays were then placed in a greenhouse with an average daytime temperature of $23.9^{\circ} \mathrm{C}$, average nighttime temperature of $18.5^{\circ} \mathrm{C}$ and a 16-hour photoperiod with supplemental light from HID 430 watt lights for warm incubation.

The location of each tray within a growth unit was randomized and tray locations within a unit were changed bi-monthly. Trays were sub-irrigated and water levels were kept consistent by filling water to the same level once each week. I recorded emergence weekly. Trays remained in the greenhouse for a 10-week period (Hogue and LaCroix 1970), at which time I removed all seeds that had not emerged. All seeds with radicles at least $1 \mathrm{~mm}$ long were considered germinated (Fowler and Fowler 1987) and all seeds without emerged radicles were then tested for viability using tetrazolium (TZ) (AOSA 2000).

I stratified 900 seeds from the same seed crop that was used for the experiment above under standard horticulture conditions (Hogue and LaCroix 1970) to examine the effect of my experimental conditions on germination. Seeds were placed in moist sand within a closed plastic bag. The seeds were then placed in a refrigerator maintained at a 
constant $5^{\circ} \mathrm{C}$ until seeds had received $840 \mathrm{~S}_{\mathrm{tt}}$ units (2016 hours). Seeds were then incubated in a greenhouse for 10 weeks in a covered tray with moist sand.

For all subsequent statistical analyses, unless otherwise indicated, I used the software package SAS v. 9.2 (SAS Institute, Cary NC, USA). I used a generalized linear mixed model (PROC GLIMMIX) with a binary distribution to test the effect of $\mathrm{S}_{\mathrm{tt}}$ units on germination. The model included the fixed effects of scarification, stratification, location and the interaction of location and scarification (the inclusion of other nonsignificant interactions changed the significance of main effects) and the random effects of chamber, tray (location and scarification nested within tray) and tree (population was excluded as a random effect because its effect was estimated to be zero). Seeds that were not viable at the end of the experiment were removed from the dataset prior to data analysis.

Mean germination time in days (MGT) was calculated using the methods described in Chien et al. (2006). MGT is a measure of the rate of germination and of the sharpness of the germination peak. A smaller number indicates a faster germination. I used a mixed effects linear model (PROC MIXED) with scarification, location, stratification and the interactions between all combinations of stratification, location, and scarification as fixed effects and chamber and tray (location and scarification nested within tray) as random effects to examine the relationship between $\mathrm{S}_{\mathrm{tt}}$ units and MGT.

\section{Chill units and bud-break}

I carried out a greenhouse experiment to determine the chilling requirement of Russian olive buds and investigated whether this chilling requirement is met south of the southern range limit. I quantified the effect of chilling on bud dormancy loss as chill units 
using the methods of Linvill (1990) (Appendix A), where each hour spent at a temperature is weighted by the effectiveness of that temperature for breaking dormancy. The model assumes a curvilinear influence of temperature on dormancy based upon experimentally observed bud response of temperature zone fruit tree to various temperatures (Erez and Lavee 1971; Erez et al. 1979; Richardson et al. 1974); the contribution of an hour toward breaking dormancy is 0 below $0^{\circ} \mathrm{C}$, rises to a maximum of 1 at $7^{\circ} \mathrm{C}$, decreases back to 0 at $14^{\circ} \mathrm{C}$, and becomes negative at higher temperatures, reaching a minimum of -1 at $25^{\circ} \mathrm{C}$ and above (Richardson et al. 1974; Linvill 1990).

I first determined the number of chill units naturally occurring at the southern range limit $\left(\sim 32^{\circ} \mathrm{N}\right.$ latitude) using daily maximum and minimum temperature and daylength values at $31.8^{\circ} \mathrm{N}, 106.4^{\circ} \mathrm{W}$ for the years $1980-2000$ (Daymet U.S. Data Center www.daymet.org). For each year, chill units were summed from the first day in the fall that accumulated positive chill units (Richardson et al. 1974) through the last day in March that accumulated positive chill units. Hourly temperature values were estimated from daily maximum and minimum values per Linvill (1990) (Appendix A). The chill unit sum for each year was averaged for 1980-2000 to estimate chill units at the southern range limit (mean Chill Units at the range limit=957; range of annual values: 649-1632).

I took a terminal bud cutting (3-5 buds long) from 34 naturalized adult trees in Loveland, Colorado $\left(40.45^{\circ} \mathrm{N}, 105.07^{\circ} \mathrm{W}\right)$ at 12 dates throughout the winter of 20092010, representing 12 different chilling treatments. On the same date that cuttings were taken from adult trees, I also took terminal bud cuttings from 34 Russian olive saplings. These saplings had been collected from Socorro and Escondida, New Mexico $\left(\sim 34.07^{\circ} \mathrm{N}\right.$, $106.90^{\circ} \mathrm{W}$ ) in January of 2009 , when trees were dormant, and transported to Fort Collins, 
Colorado $\left(40.56^{\circ} \mathrm{N}, 105.07^{\circ} \mathrm{W}\right)$. Saplings were then transplanted into 7.6 liter buckets and grown outdoors in full sun. I also moved one whole unpruned sapling into the greenhouse at the same time that cuttings were taken to investigate whether the act of taking cuttings affected chilling requirement (Farmer et al. 1975). Therefore, I had three different types of Russian olive in my experiment: adult cuttings from Colorado, sapling cuttings from New Mexico and whole saplings from New Mexico.

Accumulated chill units for each treatment were determined from temperature data collected at the time of cutting from a $\mathrm{HOBO}$ temperature data-logger (Onset, type U10-003, Bourne, Massachusetts, USA) located among the saplings. Chill units were summed from the first day in the fall with positive chill units (Richardson et al. 1974) to the date cuttings were taken to determine treatment levels $(279,434,561,593,628,670$, $763,816,913,1141,1232$, and 1322 chill units). Chill unit treatments were representative of locations north and south of the range limit. After the ninth set of cuttings, most source saplings no longer had healthy live branches from which to take cuttings; therefore, I only had nine treatments for sapling cuttings. Whole saplings and adult trees both had 12 treatments.

I placed the basal-end of the cuttings in tap-water in a greenhouse with an average daytime temperature of $23.9^{\circ} \mathrm{C}$, average nighttime temperature of $18.5^{\circ} \mathrm{C}$ and a 16 -hour photoperiod with supplemental light from HID 430 watt lights for forcing. Once cuttings and plants were moved into the greenhouse, temperatures were not effective for accumulation of positive chill units. Bud-break proportion was calculated weekly for each cutting, until the proportion no longer increased, by dividing the number of buds that burst by the total number of buds on the cutting. I then calculated the mean final bud- 
break proportion for each treatment by averaging the final proportion value for each of the 34 cuttings. Bud-break was defined as the emergence of green leaf-tips from swollen buds (Phivnil et al. 2004). Additionally, the date of first bud burst on each cutting was recorded and considered to be the date of bud-break for the cutting. For the whole plants, bud-break was recorded weekly for the entire plant.

I used a generalized linear mixed model (PROC GLIMMIX) with a binomial distribution and logistic relationship to analyze the effects of Chill Unit treatments and Bud Source (Whole Saplings, Adult Cuttings and Sapling Cuttings) on the probability of bud-break. Treatments with zero bud-break were excluded from the model and I used a constricted model including only the Chill Unit treatments (763, 816 and 913 chill units) common among all three bud sources. I used least squares means for mean separation $(\alpha<0.05)$. Additionally, I used logistic regression to analyze the effect of Chill Unit on the probability of bud-break for each bud source individually. This analysis included all Chill Unit treatments.

I used linear regression and analysis of variance (PROC GLM) to analyze the effects of Chill Unit treatment and Bud Source on the mean time until bud-break (MTB), in days. A MTB value was calculated for each cutting that exhibited bud-break by subtracting the cutting date from the date of first bud-break. Only the Sapling Cuttings and Adult Cuttings were included in the analysis because of lack of replication for Whole Saplings. Unless otherwise stated, the analyses used a full model including all the Chill Unit treatments (excluding treatments with zero bud-break) because results did not differ between full and constricted models. When comparing Bud Source mean MTB values, I used a constricted model with only the Chill Unit treatments common (763, 816, and 913 
chill units) between the two bud sources (Adult Cuttings and Sapling Cuttings). I used least squared means for mean separation $(\alpha<0.05)$.

The relationship between Chill Units and bud-break was sigmoidal with a lower asymptote approaching 0 at low Chill Units and an upper asymptote between 0 and 1 at high Chill Units. I used a nonlinear sigmoid regression of the form: $y=c /\left(1+e^{\left.\left(a^{*} b-x\right)\right)}\right)$, as described in Hoehler (1995) (Appendix A) to determine the chilling requirement. Because some of my data did not have maximum bud-break of 100-percent, I used the mid-way/inflection point of the curve, rather than 50\% bud-break (Mehlenbacher 1991; Cannell and Smith 1983; Cesarccio et al. 2004) to characterize chilling requirement. Asymptote and inflection point values were estimated for Adult Cuttings and Whole Saplings (PROC NLIN). The Adult Cutting estimates were also used to determine the chilling requirement for Sapling Cuttings because: (1) Sapling Cuttings data did not have all Chill Unit treatments and did not reach an upper asymptote; and (2) Adult Cuttings and Sapling Cuttings Bud Sources were not found to be significantly different. 


\section{CHAPTER IV: RESULTS}

\section{Occurrence and climate variables}

The distribution of Russian olive shows a southern boundary passing through southern California, Arizona, New Mexico and Texas (Fig. 1).

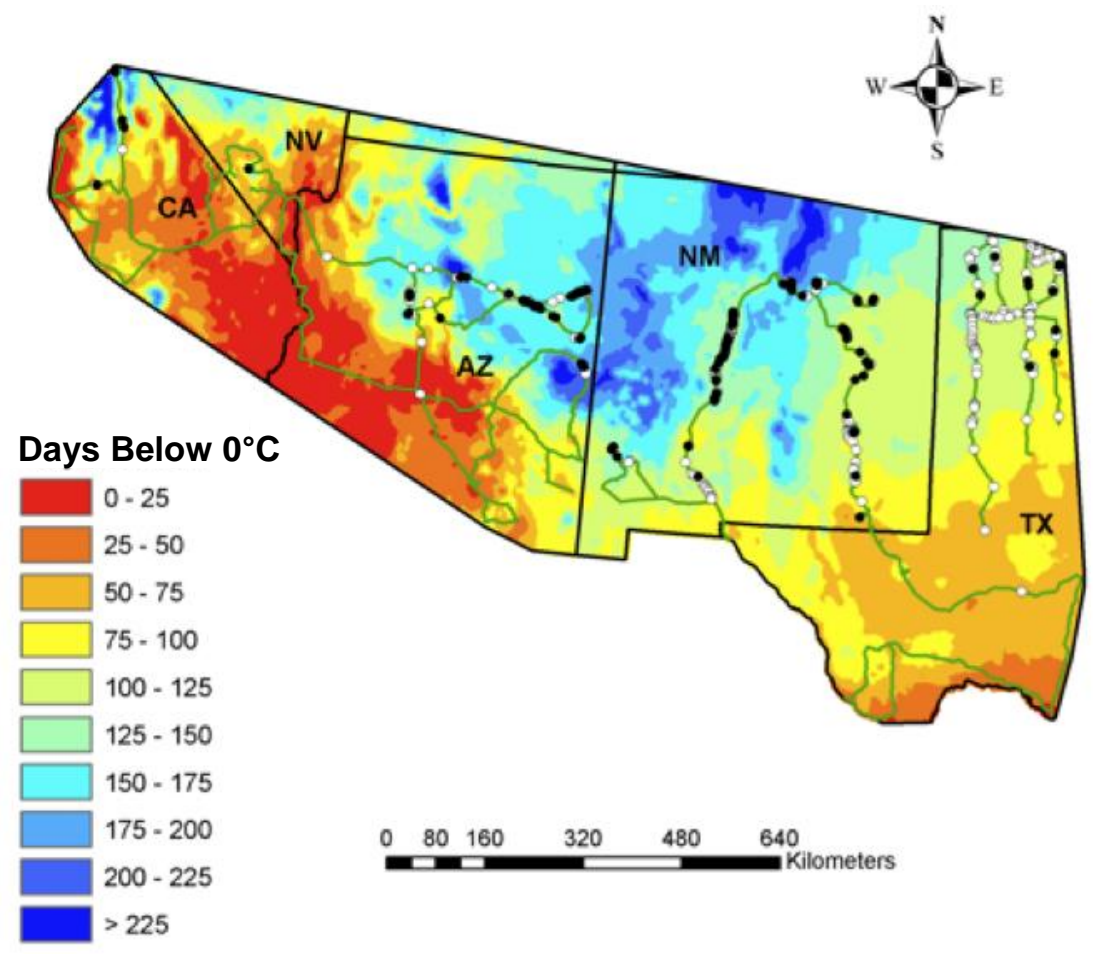

Figure 1. Locations of planted (open circles) and naturally occurring (closed circles) Russian olive in relation to mean annual number of days with temperature below $0^{\circ} \mathrm{C}$. Green lines indicate roads surveyed. CA denotes California, NV denotes Nevada, AZ denotes Arizona, NM denotes New Mexico, and TX denotes Texas.

Russian olive occurrence was more strongly related to winter low temperatures than to summer high temperatures and precipitation (Table 1). Presence of naturally occurring, but not of planted Russian olive, was negatively related to distance from water (Table 1). 
Table 1. Log pseudolikelihood and pseudo $\mathrm{r}^{2}$ generated by univariate logistic regression models predicting the occurrence of planted and naturally occurring Russian olive.

$$
\text { Naturally Occurring Planted }
$$

\begin{tabular}{lllll} 
Independent Variable & $\begin{array}{l}\text { Log pseudo } \\
\text { likelihood }\end{array}$ & Pseudo $\mathrm{r}^{2}$ & $\begin{array}{l}\text { Log pseudo } \\
\text { likelihood }\end{array}$ & Pseudo $\mathrm{r}^{2}$ \\
\hline $\begin{array}{l}\text { Annual extreme minimum } \\
\text { temperature }\end{array}$ & -642.264 & 0.126 & -874.004 & 0.131 \\
$\begin{array}{l}\text { Number of days with frost } \\
\text { Daily minimum temperature }\end{array}$ & -650.714 & 0.115 & -926.426 & 0.078 \\
$\begin{array}{l}\text { Distance to nearest stream } \\
\text { Daily mean temperature }\end{array}$ & -664.545 & 0.109 & -940.067 & 0.065 \\
Growing degree days & -675.538 & 0.081 & -945.724 & 0.059 \\
Daily maximum temperature & -699.018 & 0.049 & -957.347 & 0.048 \\
Precipitation & -731.467 & 0.005 & -995.873 & 0.009 \\
null model & -737.844 & 0.000 & -1005.271 & 0.000
\end{tabular}

Pixels containing planted individuals $(n=200)$ were found farther south than pixels containing naturally occurring individuals $(n=123$, Fig. 1$)$.

Germination and stratification thermal time units.

Stratification had a positive effect on the proportion of seeds that germinated $\left(\mathrm{F}_{1,3293}=62.09 \mathrm{p}=<0.0001\right)$, and the treatment with the most stratification also had the highest germination. The proportion of seeds that germinated varied by source location, and Las Cruces seeds experienced greater germination $\left(\mathrm{F}_{1,3293}=6.23 \mathrm{p}=0.013\right)$ (Fig. 2). Scarification $\left(\mathrm{F}_{1,3293}=2.49 \mathrm{p}=0.1147\right)$ and the scarification*stratification interaction $\left(\mathrm{F}_{1,3293}=0.98 \mathrm{p}=0.32\right)$ did not have an effect on germination. The effect of tray was estimated at $2.23 \times 10^{-22}$, the effect of chamber was estimated as 0.039 and the effect of 
tree was estimated as $1.18 \times 10^{-19}$. Germination proportion was low overall (range: 0 0.233) in my experiment. In comparison, the proportion of seeds from the same seed lot that germinated when stratified in moist sand in closed plastic bags at constant $\mathrm{T}=5^{\circ} \mathrm{C}$ in a refrigerator for $840 \mathrm{~S}_{\mathrm{tt}}$ units was 0.587 .

Mean germination time (MGT) decreased with increasing $\mathrm{S}_{\mathrm{tt}}$ units $\left(\mathrm{F}_{1,235}=13.38\right.$; $\mathrm{p}<0.0003)$ and germination times were shorter for Socorro seeds $\left(\mathrm{F}_{1,235}=6.25, \mathrm{p}=0.013\right)$ (Fig. 3).

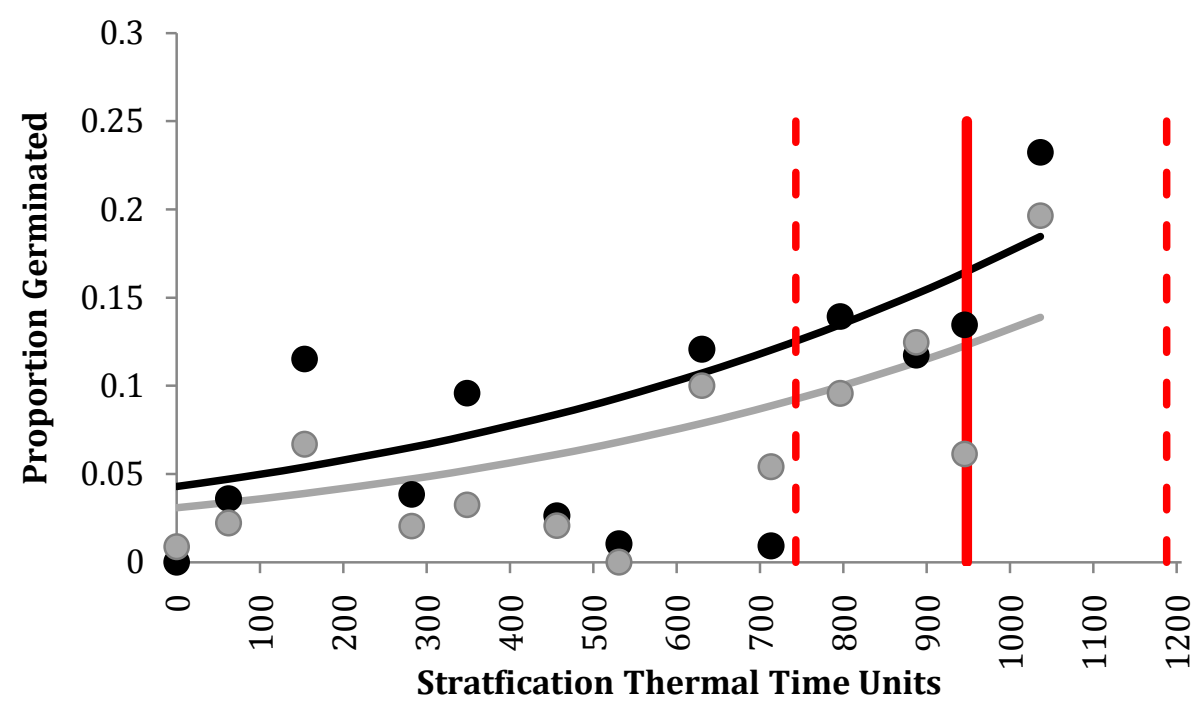

Figure 2. Proportion of Russian olive seeds germinated as a function of stratification thermal time units $\left(\mathrm{S}_{\mathrm{tt}}\right)$. Black circles denote observed Las Cruces values and the black line represents back-transformed logit Las Cruces values predicted by the model: $\mathrm{y}=$ $-3.93-0.0016 x$. Grey circles denote observed Socorro values and the grey line represents back-transformed logit Socorro values predicted by the model: $y=-3.44-0.0016 x$. The thick red line denotes the mean number of $\mathrm{S}_{\mathrm{tt}}$ units accumulated per year near the southern range limit for the years 1980-2000. The dashed red lines denote the minimum and maximum $\mathrm{S}_{\mathrm{tt}}$ units accumulated per year during this time period.

Scarification $\left(\mathrm{F}_{1,324}=0.65 \mathrm{p}=0.42\right)$ and all other interactions did not affect MGT (all $\mathrm{p}$ values $>0.38)$. 


\section{Chill units and bud-break}

Chill Units $\left(\mathrm{F}_{1,198}=26.28, \mathrm{p}<0.0001\right)$, Bud Source $\left(\mathrm{F}_{2,198}=8.34, \mathrm{p}=0.0003\right)$, and the interaction between Chill Units and Bud Source $\left(\mathrm{F}_{2,198}=6.10, \mathrm{p}=0.0027\right)$ all affected bud-

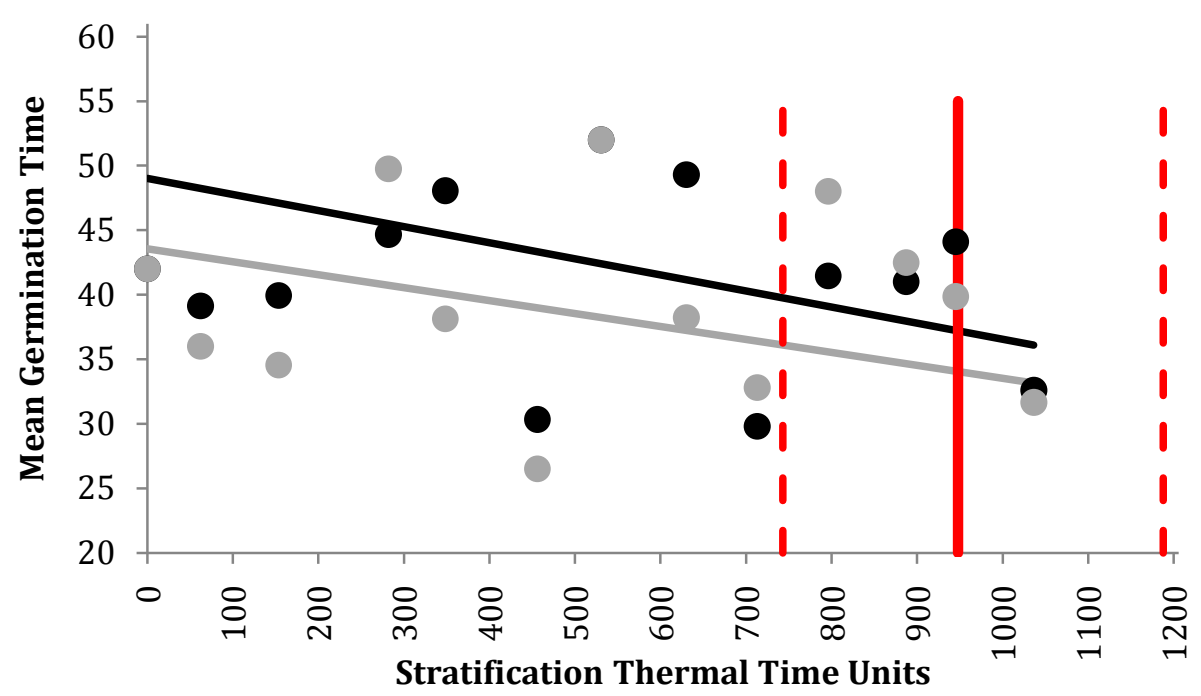

Figure 3. Mean germination time (MGT) for Russian olive seeds, in days, as a function of stratification thermal time units $\left(\mathrm{S}_{\mathrm{tt}}\right)$. Black circles denote observed values for Las Cruces seeds and the black line represents values predicted by the model: $y=49.02-0.012 x$. Grey circles denote observed values for Socorro seeds and the grey line represents values predicted by the model: $y=43.54-0.010 x$. The thick red line denotes the mean number of $\mathrm{S}_{\mathrm{tt}}$ units accumulated per year near the southern range limit for the years 1980-2000. The dashed red lines denote the minimum and maximum $\mathrm{S}_{\mathrm{tt}}$ units accumulated per year during this time period.

break for a constricted model containing only the chill treatments common among all three bud sources. Bud break after a given accumulation of chill units was not different for Adult and Sapling Cuttings ( $\mathrm{p}=0.7931$ ), but was greater for Whole Saplings than for Sapling Cuttings $(\mathrm{p}<0.0001)$. For all three of the individual Bud Source logistic regressions, Chill Units and bud-break had a significant positive relationship (Table 2, Fig. 4). Bud-break first occurred with 593 Chill Units for Whole Saplings and 763 Chill Units for both Sapling Cuttings and Adult Cuttings (Fig. 4). The chilling requirement was 


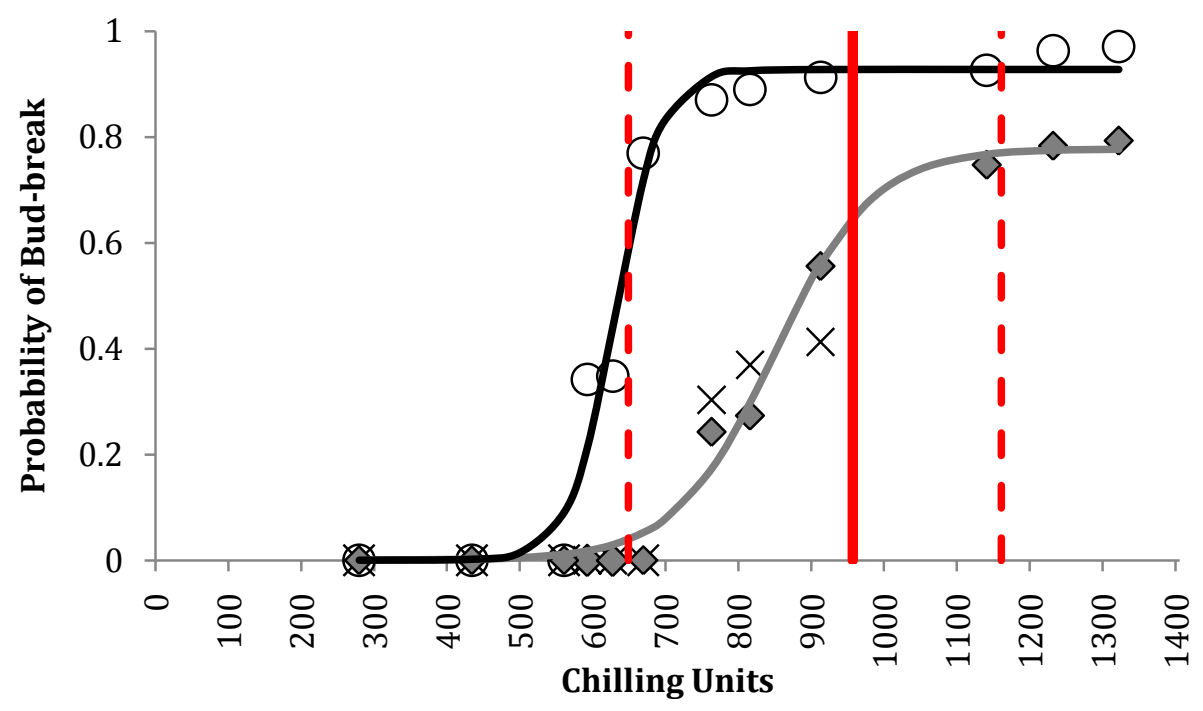

Figure 4. Probability of Russian olive bud-break as a function of Chill Units. Open black circles denote Whole Saplings (WS) observed, x's denote Sapling Cuttings (SC) observed, and closed gray diamonds denote Adult Cuttings (AC) observed. The black solid line is a sigmoid fit: $y=c /\left(1+e^{\left(a^{*}(b-x)\right)}\right)$ (Hoehler 1995) for WS and the grey line is a sigmoid fit for AC and SC. The thick red line denotes the mean number of Chill Units accumulated per year near the southern range limit for the years 1980-2000. The dashed red lines denote the minimum and maximum Chill Units accumulated per year during this time period.

631 Chill Units (95\% C.I.: 615-647 CU) for Whole Saplings and 848 Chill Units (95\% C.I.: $826-870 \mathrm{CU}$ ) for Adult cuttings and Sapling cuttings. The annual chill units accumulated at the southern range limit in the years 1980 to 2000 ranged from 649 to 1632 with a mean of 957 chill units. Insufficient chill would have led to a $10 \%$ or more decrease in bud-break in $15 \%$ of years for whole saplings and in $65 \%$ of years for adult cuttings.

Both Chill Units $\left(\mathrm{F}_{2,274}=198.020, \mathrm{p}=<0.0001\right)$ and Bud Source $\left(\mathrm{F}_{2,274}=115.890\right.$, $\mathrm{p}=<0.0001)$ affected the mean time until bud-break (MTB) (Fig. 5). Chill Units had a negative relationship with MTB; as Chill Units increased MTB decreased (Fig. 5). Additionally, Adult Cuttings required on average 7.80 more days until bud-break than Sapling Cuttings (Appendix B, Fig. 5). When type means were calculated across Chill 
Table 2: Maximum Likelihood and Odds-Ratio Estimates by type for chill units versus bud-break. Type included Whole Saplings (WS), Sapling cuttings (SC), and Adult cuttings (AC), and chill units (base $7.0^{\circ} \mathrm{C}$ ) were treated as a continuous variable (7151274 units.). The response variable was the mean bud-break proportion.

\begin{tabular}{|c|c|c|c|c|c|c|c|}
\hline Type & DF & Parameter & $\begin{array}{l}\text { Standard } \\
\text { Estimate }\end{array}$ & $\begin{array}{l}\text { Wald } \\
\text { Error }\end{array}$ & Chi-Square & $\begin{array}{l}\operatorname{Pr}> \\
\text { ChiSq }\end{array}$ & $\begin{array}{l}\text { Point } \\
\text { Estimate (x } \\
\text { increased by } 1 \\
\text { unit) }\end{array}$ \\
\hline \multirow[t]{2}{*}{ WS } & 1 & Intercept & -6.4671 & 0.3038 & 453.2461 & $<0.0001$ & 1.009 \\
\hline & & $\begin{array}{l}\text { Chilling } \\
\text { Hours }\end{array}$ & 0.00893 & 0.000435 & 421.2390 & $<0.0001$ & \\
\hline \multirow[t]{2}{*}{$\mathrm{SC}$} & 1 & Intercept & -11.8824 & 0.6622 & 318.7249 & $<0.0001$ & 1.013 \\
\hline & & $\begin{array}{l}\text { Chilling } \\
\text { Hours }\end{array}$ & 0.0132 & 0.000807 & 255.1735 & $<0.0001$ & \\
\hline \multirow[t]{2}{*}{$\mathrm{AC}$} & 1 & Intercept & -7.6305 & 0.2697 & 800.6651 & $<0.0001$ & 1.008 \\
\hline & & $\begin{array}{l}\text { Chilling } \\
\text { Hours }\end{array}$ & 0.00753 & 0.000287 & 687.1919 & $<0.0001$ & \\
\hline
\end{tabular}

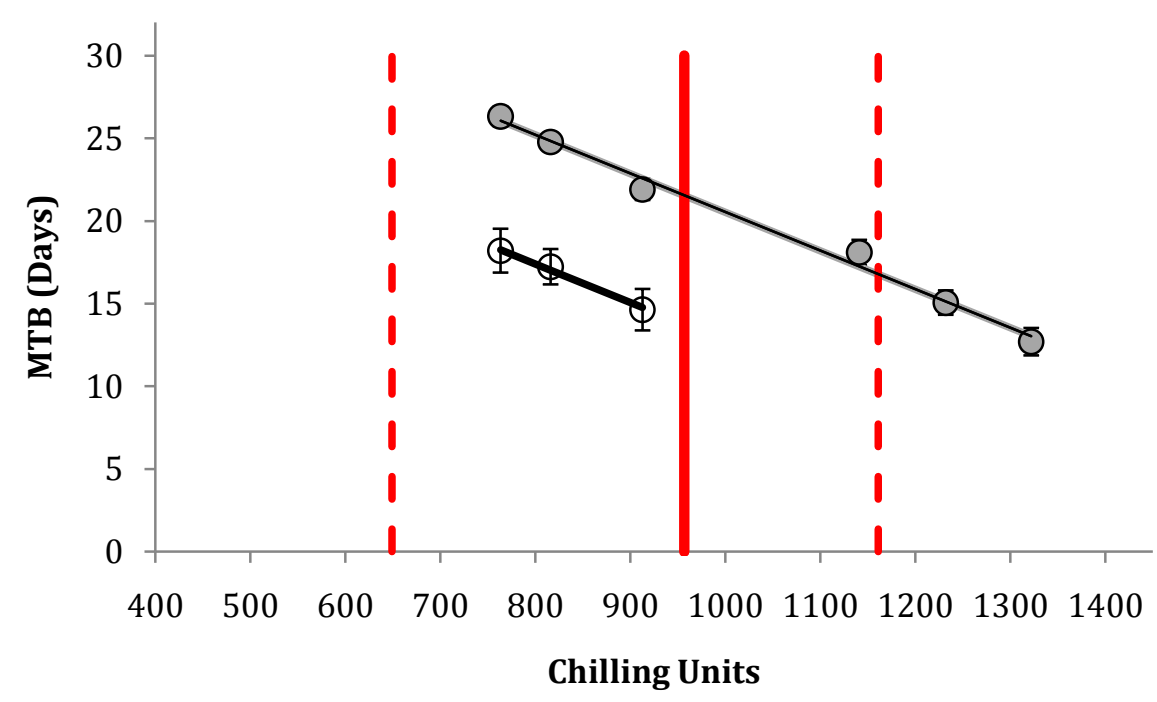

Figure 5: Mean time until Russian olive bud-break (MTB), in days, as a function of Chill Units for observed and predicted values. Open circles denote observed values for Sapling Cuttings and closed gray circles denote observed values for Adult Cuttings. Error bars represent one standard error of the mean. The black solid line represents values predicted by the model for Sapling Cuttings: $y=36.055-0.023 x\left(R^{2}: 0.992\right)$ and the grey solid line represents values predicted by the model for Adult Cuttings: $y=43.860-0.023 x\left(R^{2}\right.$ : 0.991). The thick red line denotes the mean number of Chill Units accumulated per year near the southern range limit for the years 1980-2000. The dashed red lines denote the minimum and maximum Chill Units accumulated per year during this time period. 
Unit treatments common between types (763, 816, and 913 units), MTB was longer for Adult cuttings versus Sapling cuttings (24 and 17 days, respectively) (Appendix B). 


\section{CHAPTER V: DISCUSSION}

My geographic survey documented the existence of a sharp southern distribution boundary to the distribution of Russian olive in North America, and logistic regression revealed that this limit is more strongly associated with winter low temperatures than with summer high temperatures. These results are consistent with the hypothesis that southward spread of Russian olive is limited by insufficient chilling to break bud or seed dormancy. More generally, they are consistent with many other studies that have found an association between distribution boundaries and climatic factors (see meta-analysis in Sexton et al. 2009). Because of high correlations among environmental variables, however, such associations must be considered tentative unless supported by direct experimental evidence such as my germination and bud-break experiments. The association between occurrence and distance to water for naturally occurring, but not planted, Russian olive reflects the fact that this species is typically planted in uplands but escapes to wetlands (Katz and Shafroth 2003). Additionally, it suggests that water is more important to juvenile establishment than it is to adult survival.

Germination proportion increased and germination time decreased with increasing cold stratification up to $1080 \mathrm{~S}_{\mathrm{tt}}$, which is slightly higher than the value for the southern limit of Russian olive $\left(948 \mathrm{~S}_{\mathrm{tt}}\right)$. In this experiment I had no data for $\mathrm{S}_{\mathrm{tt}}>1080$, but in an earlier experiment that tested higher $\mathrm{S}_{\mathrm{tt}}$ (Appendix C) I found maximum germination at $\mathrm{S}_{\mathrm{tt}}=1000$; furthermore, a study by Hogue and LaCroix (1970), using seeds collected in 
Manitoba, Canada, found maximum and rapid germination for $S_{\mathrm{tt}}$ units ranging from 840 to 1050 units. These results suggest that germination proportion should decline with decreased cold stratification, although I could find no consistent value in the literature below which self-replacement of temperate trees no longer occurs.

My results suggest that germination is likely to occur more slowly below the southern range limit. Slower germination times overall—and for Las Cruces seeds in general — indicate that germination probably occurs over a broader germination period below the southern range limit. The seeds in treatments representative of locations south of the range limit received very few $\mathrm{S}_{\mathrm{tt}}$ units; therefore, the seeds that germinated were those that had little or no dormancy. When seeds are relieved of dormancy, there is a widening of the range of temperatures over which germination can proceed (Bouwmeester and Karssen 1992; Schütz et al. 2002). South of the range limit emergence is likely to be sporadic and uneven. Although temperatures are mild far south of the range limit, there are still approximately 75 frost days a year in the Chihuahuan Desert of Mexico (Schmidt 1986), and seedlings could be susceptible to frost if they germinate early and drought if they germinate late. However, Russian olive is less dependent on shallow water tables than other riparian species (Reynolds and Cooper 2010; Jarnevich and Reynolds 2010) and, therefore, may not be as susceptible to drought.

Seed scarification had no effect on germination proportion. My results are inconsistent with the results of Heit (1967) who found that scarification of Russian olive seeds increased germination. It could be that my scarification treatment of soaking seeds for 40 minutes in sulfuric acid was insufficient. Heit (1967) found that soaking seeds for 1 to 2 hours was the most beneficial; however, in a previous experiment (Appendix C), I 
found that scarification of this length caused decreased germination. Removing the seed coat of Russian olive seeds was found to be beneficial (Hogue and LaCroix 1970). However, the effect of germination inhibitors in the inner and outer seed coatings and embryo (Hogue and LaCroix 1970; Hamilton and Carpenter 1976) may be more limiting than the physical structure of the seed coat itself because the seed coat of Russian olive seeds was not found to prevent water uptake-although it may limit gas exchange (Hogue and LaCroix 1970). The natural scarifying agents of Russian olive seeds are bird guts, river-bed sediment and freeze-thaw cycles. Out of these agents, freeze-thaw cycles are the only agent likely to decline toward the southern range limit. If removal of the seed coat is required, in contrast to our findings, germination should decrease toward the southern range limit.

I observed relatively low germination in this experiment even after accumulation of $1080 \mathrm{~S}_{\mathrm{tt}}$ units (range: $0-0.233$, Fig. 2). This was markedly lower than the 0.587 germination proportion I observed in seeds from the same lot held at a constant $5^{\circ} \mathrm{C}$ in moist sand for only 840 units, which is similar to the value of 0.60 obtained by Hogue and LaCroix (1970) under similar conditions. These results suggest that my experimental conditions reduced proportion germinated or caused slower elimination of dormancy than would be predicted by accumulation of $\mathrm{S}_{\mathrm{tt}}$ units. It is possible that the algorithm for calculating $\mathrm{S}_{\mathrm{tt}}$ units (Pritchard et al.1996; Handley and Davy 2005) is too liberal in accumulating $\mathrm{S}_{\mathrm{tt}}$ units outside of the range of $3-6^{\circ} \mathrm{C}$ thought to be most efficient in overcoming dormancy (Scholten 2009) or the temperature fluctuations themselves may have slowed elimination of dormancy (Stokes 1965). Thermal time models have been widely used to predict seed germination (Garcia-Huidobro et al. 1982; Ellis et al. 1986; 
Wang et al. 2004) and the thermal-time model used in this experiment is appropriate when mean daily temperatures are above freezing. Under field conditions and in colder climates, a model with a bell-shaped function that more directly weights various temperatures for their effectiveness in relieving dormancy (Seeley and Damavandy 1985) would be more appropriate.

Although temperature is arguably the most important factor regulating germination, light, moisture and nitrate levels are also important (Hilhorst 1998). More complex models, such as hydrotime models (Christensen et al. 1996; Batlla and BenechArnold 2004; Bochenek et al. 2010) that account for the effect of both temperature and moisture, could also be useful in describing germination patterns in Russian olive seeds, particularly under field conditions. It is possible that excessive moisture in my experiment slowed elimination of dormancy by inhibiting penetration of oxygen through the seed coat (Gorden and Edwards 1991; Poulsen 1996; Muller 1993). In any case, the results of this experiment, my distribution study (above) and Hogue and LaCroix (1970) are all consistent with the hypothesis that insufficient winter chill accumulation reduces germination of Russian olive seeds south of the southern distributional limit.

My bud-break experiment revealed that the chilling requirement for bud-break of adult and sapling Russian olive trees might partly determine the southern range limit. As I expected, bud-break decreased with decreasing chill units (Perry 1971; Cannell and Smith 1983; Fuchigami and Wisniewsky 1997) and the amount of forcing required for bud-break increased with decreasing chill units, which is consistent with studies of other temperature fruit trees (Cannell and Smith 1983; Myking and Heide 1995). The forcing time required for the mean number of chill units accumulated at the southern range limit 
is only three weeks for adults and two weeks for saplings. Therefore, the timing of budbreak is not likely to be limiting unless the chilling requirement is not met. However, insufficient chill would have led to a $10 \%$ or more decrease in bud-break in $15 \%$ of years for whole saplings and in $65 \%$ of years for adult cuttings. The resulting decrease in leaf area could have large fitness consequences for Russian olive trees. Decreased flowering, fruit and seed production have been documented for plants with decreased leaf area due to herbivory (Mothershead and Marquis 2000; Hochwender et al. 2003).

Whole saplings had a lower chilling requirement than sapling cuttings. By disrupting the translocation of hormones, nutrients and water in branches, the taking of cuttings appears to alter the timing of bud burst (Farmer et al. 1975). On the other hand, because adult trees often have shorter growing seasons than saplings (Cameron and Sani 1994) studies of saplings may underestimate the chilling requirement of buds on adult trees. Finally, because our whole saplings were potted, they may have received more chilling in the roots than plants in the ground, leading to an underestimate of the chilling requirement.

I observed that cuttings from adult trees in Loveland, Colorado, $\left(40.45^{\circ} \mathrm{N}\right)$ required more forcing for bud-break than cuttings from saplings from Socorro and Escondida, New Mexico (34.07 N, Fig. 5). Greater forcing requirements in adults versus immature individuals have been observed in many other deciduous temperature woody species (Gill et al. 1998; Seiwa 1999; Augspurger and Barlett 2003; Augspurger et al. 2005). The phenomenon has been termed phenological escape or avoidance of shade. Juvenile trees may have earlier leaf emergence to capture resources before adults close the canopy (Uemura 1994; Gill et al. 1998; Augspurger et al. 2004; Augspurger et al. 
2005). Alternatively, the difference in forcing requirement between saplings from New Mexico and adults from Colorado could reflect genetic variation based on latitude. Rapid evolution of latitudinal genetic variation in growth and phenology has been demonstrated in other introduced plants, including trees (Weber and Schmid 1998; Maron et al. 2004, Friedman et al. 2008; Buswell et al. 2011).

In my germination experiment, I included seeds from north of the range limit (Socorro, New Mexico $34.07^{\circ} \mathrm{N}$ latitude) and near the range limit (Las Cruces, New Mexico $32.3^{\circ} \mathrm{N}$ latitude), and detected a source location effect on germination. Overall, a greater proportion of seeds from near the range limit (Las Cruces, New Mexico $32.3^{\circ} \mathrm{N}$ latitude), germinated versus seeds from north of the range limit (Socorro, New Mexico $34.07^{\circ} \mathrm{N}$ latitude). This is what we would expect if seeds near the southern range limit were locally adapted to warmer climatic conditions. Seeds near the range limit may have lower stratification requirements, although peak germination occurred for both with $\sim 1000$ Stt units experienced higher. It is unclear whether this pattern holds in the wild; therefore, I suggest the need for reciprocal planting experiments with both seed sources. It is likely not a single life stage that is limiting Russian olive's range, but rather a combination of factors. Small fitness differences across the life cycle can accumulate and lead to large differences in overall fitness (Marshall 1968, Ehrlen 2003). I suggest that the potential for limited and delayed bud-break, combined with declining seed viability toward the range limit (Appendix E) could combine to strongly contribute to the absence of Russian olive south of $\sim 32^{\circ} \mathrm{N}$ latitude.

In North America, the most pronounced aspect of ongoing and anticipated climate warming is an increase in the winter nighttime low temperatures important for breaking 
seed and bud dormancy near the southern limit of Russian olive (IPCC 2007). Decreasing winter chill is expected to make much of southern California unsuitable for some fruit and nut varieties because of insufficient chill to overcome bud dormancy (Baldocchi and Wong 2008; Luedeling et al. 2009). Near the southern limit of Russian olive, winter warming may increase the frequency of years with reduced seed germination and incomplete bud break. The latter could cause reduced leaf area and productivity, which could lead to both reduced inter-specific competitive ability and decreased competitive ability of juvenile life stages of Russian olive trees. I observed that fewer chill units required more forcing (Murray et al. 1989). Thus, delayed (Morin et al. 2009) rather than earlier (Myneni et al. 1997; Parmesan and Yohe 2003) vegetative bud-break is likely to occur in the south under warming scenarios. Delayed bud-break has been found to hinder flower development in other temperate tree species (Prentice and Helmisaair 1991), which, in turn, can lead to decreased fruit quality (Lopez 2007), fruit set (Rattigan and Hill 1986; Rakngan et al. 1996) and fruit ripening (Morin et al. 2008). Additionally, delayed bud-break could delay fruit set and seed dispersal.

All of the above factors could greatly decrease Russian olive's fitness near the southern limit and lead to a contraction in the southern part of its range in North America. The retreat of a prevalent non-native species, such as Russian olive, may present land managers and ecologists with a unique restoration opportunity. It will be important to identify and establish native species where the range of Russian olive contracts before other undesirable species that are not likely to retreat with climate change invade and complicate restoration opportunities. In the case that native species may also be unable to reoccupy these sites as a result of climate change, 'transformative' restoration may be 
required (Bradley \& Wilcove 2009). 'Transformative' restoration involves the introduction of species indigenous to the broader eco-region that may not have been formerly present but which can preserve ecosystem functions (Harris et al 2006), such as carbon, water and nutrient cycling. Additional studies examining other factors that may contribute to Russian olive's range limit can help managers more accurately identify areas of potential contraction and inform future management decisions.

I only examined the effect of temperature on Russian olive distribution, but distributions may be limited by other abiotic factors (e.g., nutrients, precipitation and physical barriers) or biotic factors (e.g., competition and predation) affecting and interacting with local population dynamics (e.g., dispersal, colonization, immigration, fecundity, mortality, extinction), and genetic mechanisms (e.g., morphological, physiological, or ecological adaptation, and niche evolution) (Gaston 2003). It is also possible that the success of seedlings beyond the emergence stage, which I did not examine in my study, could be more sensitive to climatic characteristics at the southern range limit. My finding that naturally occurring Russian olive plants are more strongly related to water than planted Russian olive suggests the importance of the seedling stage. Drought-induced mortality (Morin et al. 2008), competition, and disease (Flannigan and Woodward 1994) can contribute to the southern range limit of plants in North America (Morin et al. 2008), particularly by hindering seedling establishment. It has been suggested that Russian olive has not yet invaded all potentially suitable habitat (Friedman et al. 2005, Reynolds and Cooper 2010). Although Jarnevich and Reynolds (2010) found potential suitable habitat to be primarily westward, rather than southward, transplant studies of seedlings south of the present perceived range limit—with and without 
competition of native and introduced species - would be particularly informative to validate our assumption of climate equilibrium at its southern range. 


\section{REFERENCES}

Augspurger CK, Barlett EA (2003) Differences in leaf phenology between juvenile and adult trees in a temperate deciduous forest. Tree Physiol 23: 517-525.

Augspurger CK (2004) Developmental versus environmental control of early leaf phenology in juvenile Ohio buckeye (Aesculus glabra). Can. J. Bot. 82: 31-36.

Augspurger CK, Cheeseman JM, Salk CF (2005) Light gains and physiological capacity of understory woody plants during phenological avoidance of canopy shade. Funct Ecol 19: 537-546.

Association of Official Seed Analysis (AOSA) (2000) Tetrazolium testing handbook. In: Contribution No. 29. Handbook on seed testing. pp 302 AOSA, Lincoln, NE.

Baldocchi D, Wong S (2008) Accumulated winter chill is decreasing in the fruit growing regions of California. Climatic Change 87: S153-S166.

Baskin JM, Baskin CC 2004. A classification system for seed dormancy. Seed Sci Res 14: 1-16.

Batlla D, Benech-Arnold RL (2004) A predictive model for dormancy loss in Polygonum aviculare L. seeds based on changes in population hydrotime parameters. Seed Sci Res 14: 277-286.

Batlla D, Grundy A, Dent KC, Clay HA, Finch-Savage, WE (2009) A quantitative analysis of temperature-dependent dormancy changes in Polygonum aviculare seeds. Weed Res 49: 428-438.

Bochenek A, Golaszewski J, Gielwanowska I (2010) Hydrotime model analysis of Matricaria maritime ssp. Inodora seed dormancy. Plant Spec Biol 25: 136-148.

Bonner FT (2008) Seed Biology In: Bonner FT, Karrfalt RP (eds) The woody plant seed manual agricultural handbook 727 pp 4-32.

Bouwmeester HJ, Karssen CM (1992) The dual role of temperature in the regulation of the seasonal changes in dormancy and germination of seeds of Polygonum persicaria L. Oecologia 90: 88-94.

Bradley BA, Oppenheimer M, Wilcove DS (2009) Climate change and plant invasions: restoration opportunities ahead? Glob Change Biol 15: 1511-1521.

Bradley BA, Wilcove DS (2009) When invasive plants disappear: Transformative restoration possibilities in the western United States resulting from climate change. Restor Ecol 17: 715-721.

Buswell JM, Moles AT, Hartley S (2011) Is rapid evolution common in introduced plant species? J Ecol 99: 214-224.

Cameron AD, Sani H (1994) Growth and branching habit of rooted cuttings collected from epicormic shoots of Betula pendula Roth. Tree Physiol 14: 427-436.

Campbell CJ, Dick-Peddie WA (1964) Comparison of phreatophyte communities on the Rio Grande in New Mexico. Ecology 45: 492-502.

Cannell MGR, Smith RI (1983) Thermal time, chill days and prediction of budburst in Picea-Sitchensis. J Appl Ecol 20: 951-963.

Cesaraccio C, Spano D, Snyder RL, Duce P (2004). Chilling and forcing model to predict bud-burst of crop and forest species. Agr and Forest Meteorol 126: 1-13.

Chien CT, Chen SY, Chang SH, Chung JD (2006) Dormancy and germination in seeds of the medicinal Asian tree species Phellodendron amurense var. wilsonii (Rutaceae). Seed Sci and Technol 34: 561-571. 
Christensen M, Meyer SE, Allen PS (1996) A hydrothermal time model of seed afterripening in Bromus tectorum L. Seed Sci Res 6:1555-1563.

Chuine I, Beaubien EG (2001) Phenology is a major determinant of tree species range. Ecol Lett 4: 500-510.

Darwin CR (1859) On the origin of species by means of natural selection, or the preservation of favored races in the struggle for life. London, John Murray.

Dogramaci M, Horvath DP, Chao WS, Foley ME, Christoffers MJ, Anderson, JV (2010) Low temperatures impact dormancy status, flowering competence, and transcript profiles in crown buds of leafy spurge. Plant Mol Biol 73: 207-226.

Ehrlen J (2003) Fitness components versus total demographic effects: evaluation herbivore impacts on a perennial herb. Am Nat 162: 796-810.

Ellis RH, Covell S, Roberts EH, Summerfield RJ (1986) The influence of temperature on seed germination rate in grain legumes. II. Intraspecific variation in chickpea at constant temperatures. J Exp Bot 39: 935-950.

Erez A, Lavee S (1971) Effect of climatic conditions on dormancy development of peach buds. 1. Temperature. J Am Soc for Hortic Sci 96: 711-714.

Erez A, Couvillon GA, Hendershott CH (1979) Quantitative chilling enhancement and negation in peach buds by high temperatures in a daily cycle. J Am Soc for Hortic Sci 108: 536-540.

Fang J, Lechowicz MJ (2006) Climatic limits for the present distribution of beech (Fagus L.) species in the world. J Biogeogr 33:1804-1819.

Farmer RE Jr, Barnett PE, Hall GC (1975) Effects of chilling and pruning in forcing dormant black cherry. Can J For Res 5:160-162.

Flannigan MD, Woodward FI (1994) Red pine abundance: current climatic and responses to future warming. Can J For Res 24: 1166-1175.

Fowler LJ, Fowler DK (1987) Stratification and temperature requirements for germination of autumn olive (Elaeagnus umbellata) seed. Tree Planters' Notes 38: 14-17.

Friedman JM, Auble GT, Scott ML, Merigliano MF, Freehling MD, Griffin ER (2005) Dominance of non-native riparian trees in western USA. Biol Invas 7: 747-751.

Friedman JM, Roelle JM, Gaskin JF, Pepper AE, Manhart JR (2008) Latitudinal variation in cold hardiness in introduced Tamarix and native Populus Evol Appl 1: 598607.

Fuchigami LH, Wisniewsky M (1997) Quantifying bud dormancy: physiological approaches. HortScience 32: 618-623.

Garcia-Huidobro J, Monteith JL, Squire GR (1982) Time, temperature and germination of pearl millet (Pennisetum typhoides $S$. \& H) I. Constant temperature. J Exp Bot 33: 297-302.

Gaston KJ (2003). The structure and dynamics of geographic ranges. Oxford, UK, University Press.

Ghelardini L, Santini A, Black-Samuelsson S, Myking T, Falusi M (2009) Bud dormancy release in elm (Ulmus spp.) clones-a case study of photoperiod and temperature responses. Tree Physiol 30: 264-274.

Gill DS, Amthor JS, Bormann FH (1998) Leaf phenology, photosynthesis, and the persistence of saplings and shrubs in a mature northern hardwood forest. Tree Physiol 18: 281-289. 
Gordon AG, Edwards DGW (1991) Testing the germination of tree and shrub seeds. In: Gordon AG et al. (eds) Tree and shrub seed handbook. The International Seed Testing Association, Zurich, pp 5-8.

Guisan A, Zimmermann NE (2000) Predictive habitat distribution models in ecology. Ecol Model 135: 147-186.

Hamilton DF, Carpenter PL (1976) Regulation of seed dormancy in Elaeagnus angustifolia by endogenous growth substances. Can J Bot 54: 1068-1073.

Handley RJ, Davy AJ (2005) Temperature effects on seed maturity and dormancy cycles in an aquatic annual, Najas marina, at the edge of its range. J Ecol 93: 1185-1193.

Harlan A, Dennis AE (1976). A preliminary plant geography of Canyon de Chelly National Monument. J Ari Aca Sci 11: 69-78.

Harris JA, Hobbs, RJ, Higgs E, Aronson J (2006) Ecological restoration and global climate change. Restor Ecol 14: 170-176.

Heit CE (1967) Propagation from seed: 6. Hard-seededness-a critical factor. Am Nurseryman 125: 10-12, 88-96.

Hilhorst HWM (1998) The regulation of secondary dormancy. The membrane hypothesis revisited. Seed Sci Res 8: 77-90.

Hochwender CG, Sork VL, Marquis RJ (2003) Fitness consequences of herbivory on Quercus alba. Am Midl Nat 150: 246-253.

Hogue, EJ, LaCroix LJ (1970) Seed dormancy of Russian olive (Elaeagnus angustifolia L.) J Am Soc for Hortic Sci 95:449-452.

Hoehler FK (1995) Logistic equations in the analysis of s-shaped curves. Comput Biol Med 25: 367-371.

Intergovernmental Panel on Climate Change (IPCC) (2007) Climate change 2007: The physical science basis. Contribution of working group I to the fourth assessment report of the intergovernmental panel on climate change. Cambridge University Press, Cambridge.

Jarnevich CS, Reynolds LV (2010) Challenges of predicting the potential distribution of a slow-spreading invader: a habitat suitability map for an invasive riparian tree. Dig Biol Invasions DOI 10.1007/s/10530-010-9798-4

Jarnevich CS, Stohlgren TJ (2009) Near term climate projections for invasive species distributions. Biol Invas 11: 1373-1379.

Katz GL, Shafroth PB (2003) Biology, ecology and management of Elaeagnus angustifolia L. (Russian olive) in western North America. Wetlands 23: 763-777.

Khan MA, Ungar IA (1984) The effect of salinity and temperature on the germination of polymorphic seeds and growth of Atriplex triangularis Willd. Am J Bot 71: 481489.

Kriticos DJ, Sutherst RW, Brown JR, Adkins SW, Maywald GF (2003) Climate change and the potential distribution of an invasive alien plant: Acacia nilotica ssp indica in Australia. J Appl Ecol 40: 111-124.

Linvill DE (1990) Calculating chilling hours and chill units from daily maximum and minimum temperature observations. HortScience 25: 14-16.

Lopez G, Scott JR, Dejong TM (2007) High spring temperatures decrease peach fruit size. Calif Agric 61: 31-34.

Luedeling E, Zhang M, Girvetz EH (2009) Climatic changes lead to declining winter chill for fruit and nut trees in California during 1950-2099. PLoS ONE 4: e6166 
DOI 10.1371/journal.pone.0006166

MacArthur RH (1972) Geographical Ecology. Harper and Row, New York, New York.

Maron JL, Vila M, Bommarco R, Elmendorf S, Beardsley P (2004) Rapid evolution of an invasive plant. Ecol Monogr 74: 261-280.

Marshall JK (1968) Factors limiting the survival of Corynephorus canescens L. Beauv. in Great Britain at the northern edge of its distribution. Oikos 19: 206-216.

Mehlenbacher SA (1991). Chilling requirements of hazelnut cultivars. Sci HorticAmsterdam 47: 271-282.

Mothershead K, Marquis RJ (2000) Fitness impacts of herbivory through indirect effects on plant-pollinator interactions in Oenothera Macrocarpa. Ecol 81: 30-40.

Morin X, Augspurger C, Chuine I (2007) Process-based modeling of species' distributions: what limits temperate tree species' range boundaries? Ecology 88: 2280-2291.

Morin X, Viner D, Chuine I (2008) Tree species range shifts at a continental scale: new predictive insights from a process-based model. J Ecol 96: 784-794.

Morin X, Lechowicz MJ, Augspurger C, O'Keefe JO, Viner D, Chuine, I (2009) Leaf phenology in 22 North American tree species during the 21st century. Glob Change Biol 15: 961-975.

Muller C (1993) Combination of dormancy-breaking and storage for tree seeds: new strategies for hardwood species. In: Edwards, DGW (ed) Dormancy and barriers to germination. Proceedings, Symposium of IUFRO Project Group P2.04-00, Seed Problems. 1991 April 23-26, Victoria, BC pp 87-95.

Murray MB, Cannell MGR, Smith RI (1989) Date of budburst of fifteen tree species in Britain following climatic warming. J Appl Ecol 26: 693-700.

Myking T, Heide OM (1995) Dormancy release and chilling requirement of buds of latitudinal ecotypes of Betula pendula and B. pubescens. Tree Physiol 15: 697704.

Myneni RB, Keeling CD, Tucker CJ, Asrar G, Nemani RR (1997) Increasing plant growth in the northern high latitude from 1981 to 1991. Nature 386: 698-702.

Olson DF Jr (1974) Elaeagnus L. elaeagnus In: Schopmeyer, CS (ed) Seeds of woody plants in the United States. Agricutural Handbook 450.

Parmesan C, Yohe G (2003) A globally coherent fingerprint of climate change impacts across natural systems. Nature 421: 37-42.

Pearce CM, Smith DG (2001) Plains cottonwood's last stand: Can it survive invasion of Russian olive onto the Milk River, Montana floodplain? Environ Manage 28: 623-637.

Pearson RG, Dawson TP (2003) Predicting the impacts of climate change on the distribution of species: are bioclimate envelope models useful? Global Ecol Biogeogr 12: 361-371.

Perry TO (1971) Dormancy of trees in winter. Science 171: 29-36

Peterson AT, Papes M, Kluza DA (2003) Predicting the potential invasive distributions of four alien plant species in North America. Weed Sci 51: 863-868.

Phivnil K, Beppu K, Mochioka R, Fukuda T, Kataoka I (2004) Low-chill trait for endodormancy completion in Actinidia arguta Planch. (Sarunashi) and A. rufa Planch. (Shima-saunashi), Indigenous Actinidia species in Japan and their interspecific hybrids. J Jpn Soc Hortic Sci 73: 244-246. 
Poulsen KM (1996) Prolonged cold, moist pretreatment of conifer seeds at controlled moisture content. Seed Sci and Technol 24: 75-87.

Prentice IC, Helmisaari H (1991) Silvics of north European trees: Compilation, comparisons and implications for forest succession modeling. Forest Ecol Manag 42: 79-93.

Pritchard HW, Tompsett PB, Manger KR (1996) Development of a thermal time model for the quantification of dormancy loss in Aesculus hippocastanum seeds. Seed Sci Res 6: 127-135.

Rakngan J, Gemma H, Iwahori S. (1996) Phenology and carbohydrate metabolism of Japanese pear trees grown under continuously high temperatures. J Jpn Soc Hortic Sci 65: 55-65.

Rallo L, Martin GC (1991) The role of chilling in releasing olive floral buds from dormancy. J Am Soc for Hortic Sci 116: 1058-1062.

Rattigan K, Hill SJ (1986) Relationship between temperature and flowering in almond. Aust J of Exp Agric 26: 399-404.

Reynolds LV, Cooper DJ (2010) Environmental tolerance of an invasive riparian tree and its potential for continued spread in the Southwestern US. J Veg Sci (in press) DOI: $10.1111 /$ j. 1654-1103.2010.01179.x

Richardson EA, Seeley SD, Walker DR (1974) A model for estimating the completion of rest for 'Redhaven' and 'Alberta' peach trees. HortScience 9: 331-332.

Scholten M, Donahue J, Shaw NL, Serpe MD (2009) Environmental regulation of dormacy loss in seeds of Lomatium dissectum (Apiaceae). Ann Bot 103: 10911101 .

Schütz W, Milberg P, Lamont BB (2002) Seed dormancy, after-ripening and light requirement of four annual Asteraceae in South-western Australia. Ann Bot 90:707-714.

Schmidt RH Jr (1986) Chihuahuan climate. In: Barlow JC, Powell MA, Timmermann BN (eds) Procedings of the Second Symposium on the Resources of the Chihuahuan Desert Region Chihuahuan Desert Research Institute, October 20-21 Alpine, Texas pp 40-63.

Seeley SD, Damavandy H (1985) Response of seed of seven deciduous fruits to stratification temperatures and implications for modeling. J Amer Soc Hort Sci 110: 726-729.

Seiwa K (1999) Changes in leaf phenology are dependent on tree height in Acer mono, a deciduous broad-leaved tree. Ann Bot 83: 355-361.

Sexton JP, McIntyre PJ, Angert AL, Rice KJ (2009) Evolution and ecology of species range limits. Annu Rev of Ecol Evol Syst 40: 415-436.

Shafer SL, Bartlein PJ, Thompson RS (2001) Potential changes in the distributions of western North America tree and shrub taxa under future climate scenarios. Ecosystems 4: 200-215.

Shafroth PB, CA Brown, DM Merritt (2010) Saltcedar and Russian olive control demonstration act science assessment. U.S. Geological Survey Scientific Investigations Report 2009-5247. U.S. Department of the Interior, U.S. Geological Survey, Reston, VA. 143 p.

Stokes P (1965) Temperature and seed dormancy. In: Ruhland W(ed.) Encyclopedia of Plant Physiology Springer-Verlag, Berlin. pp 746-796. 
Sykes MT, Prentice IC, Cramer W (1996) A bioclimatic model for the potential distributions of north European tree species under present and future climates. $\mathrm{J}$ Biogeogr 23: 203-233.

Thomsen MA, D'Antonio CM, Suttle KB, Sousa WP (2006) Ecological resistance, seed density and their interactions determine patterns of invasion in a California coastal grassland. Ecol Lett 9: 160-170.

Thuiller W (2004) Patterns and uncertainties of species' range shifts under climate change. Glob Change Biol 10: 2020-2027.

Timson J (1965) New method of recording germination data. Nature 207: 216-217.

Uemura S (1994). Patterns of leaf phenolgy in forest understory. Can J Bot 72: 409-414.

Vitousek PM, Dantonio, CM, Looper LL, Westbrooks R (1996) Biological invasions as global environmental change. Am Sci 84: 468-478.

Wang R, Bai Y, Tanino K (2004) Effect of seed size and sub-zero imbibition-temperature on the thermal time model of winterfat (Eurotia lanataI (Pursh) Moq.). Environ Exp Bot 51: 183-197.

Weber E, Schmid B (1998) Latitudinal population differentiation in two species of Solidago (Asteraceae) introduced into Europe. Am J Bot 85: 1110-1121.

Williams AL, Wills, KE, Janes JK, Schoor JKV, Newton PCD, Hovenden MJ (2007) Warming and free-air $\mathrm{CO}_{2}$ enrichment alter demographics in four co-occurring grassland species. New Phytol 176: 365-374.

Wooton EO, Standley PC (1915) Flora of New Mexico. Contr US Nat Herb 19, US Govt Printing Office, Washington DC, 794 pp. 


\section{APPENDIX A: EXPANDED METHODS.}

\section{Chilling for seeds (cold stratification)}

The effect of stratification on dormancy can be quantified using a thermal time model, which accumulates degree-days below a ceiling threshold temperature (above this temperature dormancy release does not occur) (Handley and Davy 2005). These are commonly referred to as stratification thermal time units $\left(\mathrm{S}_{\mathrm{tt}}\right.$ units $)$. The upper threshold above which dormancy release no longer occurs is approximately $15^{\circ} \mathrm{C}$, although it varies by species (Batlla et al. 2009, Stokes 1965, and Roberts 1988). Accumulated stratification thermal time units are calculated by summing the daily difference between mean

temperature and the ceiling temperature using the following equation: $\mathrm{S}_{\mathrm{tt}}=\sum^{d=n ; d=1}\left(\mathrm{~T}_{c}-\mathrm{T}_{d}\right)$ for $T>T_{d}$ where $\mathrm{S}_{\mathrm{tt}}$ is the stratification thermal time units below the ceiling temperature $\left(T_{c}\right.$, set at $\left.15^{\circ} \mathrm{C}\right)$ and $T_{d}$ is the mean temperature for day $\mathrm{d}$.

To determine the approximate locations to which various $\mathrm{S}_{\mathrm{tt}}$ unit treatments corresponded, I used maximum and minimum temperature data for the months of October through May from 1980-2000 (Daymet U.S. Data Center www.daymet.org) for various locations along the $\sim 107^{\circ} \mathrm{W}$ latitudinal gradient south of $32.30^{\circ} \mathrm{N}$. For each month, I averaged daily maxima and minima to calculate a mean monthly minimum and mean monthly maximum value for each year, and averaged these values for each for 1980-2000 to obtain overall monthly mean maximum and mean minimum values. Hourly temperature values were then estimated from these mean monthly maximum and 
minimum values as described below and used to calculate a daily mean. A mean daily $S_{t t}$ value was then calculated for each month and multiplied by the number of days in that month. Monthly $S_{t t}$ values were then summed for approximate mean $S_{t t}$ units per year values.

Seed germination rates

The rate of germination was estimated using two metrics. The first metric was a modified Timson index (Timson 1965, Khan and Ungar 1984); germination velocity $(\mathrm{GV})$ was determined using the following equation: $G V=\sum G / t$ where $\mathrm{G}$ is the percentage of seed germination at each interval where new germination occurred and $t$ is the total germination period. The higher GV value indicates a more rapid rate of germination. The second metric was mean germination time (MGT) in days (Chien et al. 2006). MGT was calculated using the following equation: $M G T=\left(\sum n_{i} t_{j}\right) / N$, where $\mathrm{n}_{\mathrm{i}}$ is the number of seeds germinated in $t_{i}$ days from when seeds were moved into the greenhouse, and $\mathrm{N}$ is the total number of germinated seeds at the end of the experiment. MGT is a measure of the rate of germination and of the sharpness of the germination peak. A smaller number indicates a faster germination rate. MGT and GV values were corrected for unequal greenhouse incubation times by multiplying values by correction factors. Correction factors were determined separately for each $\mathrm{S}_{\mathrm{tt}}$ unit treatment by dividing the longest incubation time (days) by each treatment incubation time (days).

\section{Calculating hourly temperature values from maximum and minimum temperature data}

The temperature wave from sunrise to sunset was determined using the following equation: $T(t)=\left(T_{\max }-T_{\min }\right)^{*} \operatorname{SIN}\left[\left(\pi^{*} t\right) /(D L+4)\right]+T_{\min }$, where $\mathrm{T}(\mathrm{t})$ was temperature at time $\mathrm{t}$ after sunrise; $\mathrm{T}_{\max }$ is maximum temperature; $\mathrm{T}_{\min }$ is the morning minimum temperature, 
and DL is day length (in hours). Night-time cooling started at sunset and was determined by the following equation: $\left.T(t)=T_{s^{-}}\left[T_{s^{-}} T_{\min }\right) / \ln (24-D L)\right]^{*} \ln (t)$, where $\mathrm{T}(t)$ is temperature at time $\mathrm{t}>1 \mathrm{hr}$ after sunset and $\mathrm{T}_{\mathrm{s}}$ is the sunset temperature calculated from the sunrise to sunset equation (Linvill 1990).

\section{Chilling for buds (chill units)}

For buds, chilling can be quantified as chill units (CU), in which hours are weighted by the effectiveness of temperatures for breaking dormancy (Linvill 1990, Richardson et al. 1974). The contribution of an hour toward breaking dormancy is 0 below $0^{\circ} \mathrm{C}$, rises to a maximum of 1 at $7^{\circ} \mathrm{C}$, decreases back to 0 at $14^{\circ} \mathrm{C}$, and becomes negative at higher temperatures, reaching a minimum of -1 at $25^{\circ} \mathrm{C}$ and above. For temperatures between $0^{\circ} \mathrm{C}$ and $25^{\circ} \mathrm{C}$, chill units are determined using the following equation: $C U=\operatorname{SIN}\left((2 \pi / 28)^{*} T\right)$, where T equals temperature (Linvill 1990).

\section{Determining Chilling Requirement}

The chilling requirement for bud-break is often determined as the predicted number of Chill Units required for 50\% bud-break (Mehlenbacher 1991, Cannell and Smith 1983, Cesarccio et al. 2004). This was not appropriate for some of our data because the maximum bud-break was not $100 \%$. The relationship between Chill Units and bud-break was sigmoidal with a lower asymptote approaching 0 at low Chill Units and an upper asymptote between 0 and 1 at high Chill Units. I determined the chilling requirement as the mid-way point of the curve, rather than $50 \%$ bud-break, using a nonlinear sigmoid regression of the form: $y=c /\left(1+e^{\left.\left(a^{*} b-x\right)\right)}\right)$, where $c$ is the upper asymptote, $a$ is the rate at which the function approaches the asymptote over time, and $b$ 
is the inflection point of the curve (the midway point/chilling requirement) (Hoehler 1995). 


\section{APPENDIX B: ADDITIONAL TABLES}

Table B1: Treatments with corresponding stratification thermal time units $\left(\mathrm{S}_{\mathrm{tt}}\right.$ unitsdegree days below $15^{\circ} \mathrm{C}$ ). Growth units had a consistent sinusoidal temperature regime with $8.64 \mathrm{~S}_{\mathrm{tt}}$ units per day. $\mathrm{S}_{\mathrm{tt}}$ units correspond to approximate latitudes along $\sim 107^{\circ} \mathrm{W}$ longitude. Latitude could not be determined for less than $328.32 \mathrm{~S}_{\mathrm{tt}}$.

\begin{tabular}{llll}
\hline Treatment \# & $\begin{array}{l}\text { Days in Temperature } \\
\text { Regime }\end{array}$ & $\#$ of $\mathrm{S}_{\mathrm{tt}}$ units & $\begin{array}{l}\text { Corresponding } \\
\text { Latitude }\left({ }^{\circ} \mathrm{N}\right)\end{array}$ \\
\hline 1 & 0 & 0 & \\
2 & 6 & 51.84 & \\
3 & 16 & 138.24 & \\
4 & 27 & 233.28 & \\
5 & 38 & 328.32 & 29.26 \\
6 & 49 & 423.36 & 29.56 \\
7 & 60 & 518.4 & 29.98 \\
8 & 71 & 613.44 & 30.40 \\
9 & 82 & 708.48 & 30.81 \\
10 & 93 & 803.52 & 31.23 \\
11 & 104 & 898.56 & 31.65 \\
12 & 114 & 984.96 & 31.8 \\
13 & 125 & 1080 & 32.30 \\
\hline
\end{tabular}

Table B2. Stratification Thermal Time Units and Mean Germination Time (MGT). The smaller the MGT value the faster the germination rate.

\begin{tabular}{ll}
\hline Trt & MGT \\
\hline 0 & 42 \\
64.78 & 37.92 \\
159.79 & 37.81 \\
293.68 & 46.23 \\
362.76 & 44.75 \\
475.06 & 28.8 \\
552.8 & 52 \\
656.45 & 44.77 \\
742.83 & 30 \\
829.2 & 43.73 \\
924.21 & 41.75 \\
984.68 & 42.92 \\
1080 & 32.17 \\
\hline
\end{tabular}


Table B3. Mean time until bud-break (MTB) by Bud Source and treatment. Treatments had varying levels $(716,768$, and 865, 1093, 1184, and 1274 units) of chill units (CU) (each hour spent at a specific temperature - constant $=\pi^{*} 2 / 28$, sine is computed in radians; Linvill, 1990) and Bud Source included Sapling cuttings (SC) and Adult cuttings (AC).

\begin{tabular}{llll}
\hline Bud Source & CU Level (hrs) & Mean (Days) & S.E.M $( \pm)$ \\
\hline AC & Overall Mean & 24 & 1.293 \\
AC & 763 & 26 & 0.602 \\
AC & 816 & 25 & 0.546 \\
AC & 913 & 22 & 0.644 \\
AC & 1141 & 18 & 0.763 \\
AC & 1232 & 15 & 0.737 \\
AC & 1322 & 13 & 0.830 \\
SC & Overall Mean & 17 & 1.065 \\
SC & 763 & 18 & 1.325 \\
SC & 816 & 17 & 1.070 \\
SC & 913 & 14 & 1.253 \\
\hline
\end{tabular}




\section{INTRODUCTION TO SUPPLEMENTARY MATERIAL}

The appendices that follow (Appendix C-F) consist of a preliminary germination experiment, preliminary bud-break experiment, field data on vegetative and flowering growth and a field survey on fruit production and seed viability at various latitudes. The preliminary bud-break and germination experiments were exploratory in nature and were used primarily to build hypotheses for secondary experiments. The field data and survey were excluded from the main text of the thesis because they did not directly relate to my hypothesis that chilling requirement limits the southward spread of Russian olive in western North America. 
APPENDIX C: PRELIMINARY GERIMATION EXPERIMENT: GERMINATION

NORTH AND SOUTH OF AND NEAR THE RANGE LIMIT, 2009-2010

METHODS

Experimental design

I collected fruit in early fall 2008 from healthy, naturalized trees $(n=26)$ along the middle Rio Grande in five populations (pop. $1 \mathrm{n}=2$, pop. $2 \mathrm{n}=3$, pop. $3, \mathrm{n}=17$, pop. $4 \mathrm{n}=3$, pop. $5 \mathrm{n}=2)$ separated by 500 meters near Socorro, New Mexico $\left(\sim 34.07^{\circ} \mathrm{N}, 106.90^{\circ} \mathrm{W}\right)$. I gave each tree a unique number and population identifier. To cold-stratify seeds, I handremoved the flesh from seeds and placed them in moist sand, $1.5 \mathrm{~cm}$ below the surface, in $25.4 \mathrm{~cm}$ x $50.8 \mathrm{~cm}$ trays divided into 125 cells (one seed per cell). Each tray received 125 seeds and at least four seeds from each tree. I randomly assigned seeds to cells and distributed seeds from each parent tree equally among trays to control for inter- and intrapopulation variability.

I quantified the effect of cold-stratification (stratification thermal time units) on seed dormancy using a linear thermal-time model as described in Handley and Davy (1995) (Appendix A). My experiment included seven treatments (Control-0, South-197, South- 233, Intermediate-821, Intermediate-1023, North-1138, North-1507) crossed with two scarification treatments (scarified and non-scarified) because Russian olive seeds sometimes exhibit seed-coat dormancy (Heit 1967). Each treatment was expressed in terms of $S_{t t}$ units accumulated over the course of the experiment. To scarify (soften and/or break the hard seed coat), I soaked seeds in $98 \%$ concentrated sulfuric acid for one hour 
(Heit 1967). The scarification treatment was applied to an entire tray. Two trays were included for each temperature by scarification treatment.

The $\mathrm{S}_{\mathrm{tt}}$ units of each treatment corresponded to locations along a latitudinal gradient at $\sim 107^{\circ} \mathrm{W}$ longitude (Table $\mathrm{C} 1$ ). I used maximum and minimum

Table C1: Temperature treatments and corresponding latitudes. The closest city is listed and whether the treatment is north or south of the range limit. The number of stratification thermal time units is listed for reference but was not a treatment. Exact latitudes and locations could not be determined for South treatments. $\mathrm{N}$ denotes north, $\mathrm{S}$ denotes south and I denotes intermediate.

\begin{tabular}{llll}
\hline Treatment & $\sim$ Latitude $\left({ }^{\circ} \mathrm{N}\right)$ & Closest City & $\begin{array}{l}\text { North or South of Range } \\
\text { Limit }\end{array}$ \\
\hline N-1507 & 33.86 & Socorro, NM & North \\
N-1138 & 33.23 & $\begin{array}{l}\text { Truth or Consequences, } \\
\text { NM }\end{array}$ & North \\
I-1023 & 32.30 & Las Cruces, NM & North \\
Range Limit-929 & 31.8 & El Paso & \\
I-821 & 31.65 & Socorro, TX & South \\
S-233 & Below 29.56 & South of Presidio, TX & South \\
S-197 & Below 29.56 & South of Presidio, TX & South \\
\hline
\end{tabular}

temperature data for the months of October through May from 1980-2003 (Daymet U.S.

Data Center, http://www.daymet.org) to determine these locations. I averaged daily minima a and maximfor a mean monthly minimum and mean monthly maximum value, respectively, for each year, and calculated the mean of these monthly minimum and maximum values for 1980-2003 to obtain overall monthly mean minimum and mean maximum values. Hourly temperature values were estimated from the mean monthly minimum and maximum values using the methods of Linvill (1990) (Appendix A). I then 
calculated $S_{t t}$ units for each month and summed monthly values for a mean value of $S_{t t}$ units per year.

Trays $(n=26)$ were placed in growth units for cold stratification treatments. The North treatments were programmed with a temperature regime corresponding to a location along the Rio Grande (Socorro, NM $\left.34.07^{\circ} \mathrm{N}\right)$ north of the range limit $\left(\sim 32^{\circ} \mathrm{N}\right.$ latitude). The South treatments were programmed with a temperature regime corresponding to a location along the Rio Grande (Presidio, TX $29.56^{\circ} \mathrm{N}$ ) south of the range limit. Trays in the Intermediate treatments started in the North units and were then moved to the South units midway through the experiment to simulate an intermediate temperature regime. Trays in the Control treatment $(n=2)$ received no $S_{t t}$ units and were placed in a greenhouse with an average daytime temperature of $23.9^{\circ} \mathrm{C}$, average nighttime temperature of $18.5^{\circ} \mathrm{C}$ and a 16 -hour photoperiod with supplemental light from HID 430 watt lights.

For both of the North and South treatments, I determined monthly diurnal temperature regimes for the months of October through May using daily minimum and maximum temperature values from the years 1980-2003 (data were acquired online from the Daymet U.S. Data Center, http://www.daymet.org). For each year, I averaged these daily minima and maxima for a mean monthly minimum and mean monthly maximum value, respectively, and then calculated the mean of these values for 1980-2003 to determine monthly diurnal temperature regimes for each location. The daily maximum and minimum remained consistent for the duration of one month and then changed according to the next month's values (Table C2). Throughout the course of the 
experiment the mean difference between the sand temperature and air temperature was \pm $1.312^{\circ}$

The north temperature regime was applied in two growth units: a growth chamber (approximately: height $\mathrm{x}$ width $\mathrm{x}$ depth; $208 \mathrm{x} 208 \mathrm{x} 253 \mathrm{~cm}$ ) and an incubator (approximately: $125 \times 65 \times 65 \mathrm{~cm}$ ). The growth chamber was capable of a sinusoidal temperature curve, whereas, the incubator was only capable of step-wise changes between daily maxima and minima. For the incubator unit, the maximum temperature was applied for the duration of average monthly day length (Table C2). Sine curves were determined using the following equation: $(\max +\min ) / 2+(\max -\min ) / 2 * \operatorname{SIN}\left(2 \pi^{*}(t-9) / 24\right)$, where $t=$ hour in military time and "9" sets the phase so that the maximum is at $3 \mathrm{pm}$ and the minimum at $3 \mathrm{am}$. Relative humidity was similar between the two growth units (mean \pm S.E.M; chamber: $67.0 \% \pm 0.097$; incubator: $71.6 \% \pm 0.089$ ). The south temperature regime was applied in two growth units: a growth chamber $(260.1 \times 111.8 \times 152.4 \mathrm{~cm}$ and an incubator unit $(66 \times 111.8 \times 152.4 \mathrm{~cm})$.

Both of the growth units used for the south temperature regimes were capable of sinusoidal temperature curves. Relative humidity was similar between the two growth units (mean \pm S.E.M growth: $68.0 \% \pm 0.15$; incubator: $67.6 \% \pm 0.079$ ). Temperature regimes were truncated based upon the temperature limits of the growth units and programmed temperatures did not go below these limits, although the natural regimes did in some months $\left(0^{\circ} \mathrm{C}\right.$ for the north regime and $4^{\circ} \mathrm{C}$ for the south regime). The locations of trays within growth units were randomized and changed bi-monthly. To keep the sand moist, trays were sub-irrigated and water was added to trays only when the water reservoir appeared dry to prevent mold from developing. I recorded seedling emergence 
or lack of emergence three times each week. A seedling was considered to have emerged when cotyledons appeared above the surface the sand. After 8 months in the growth units, I moved the trays to the greenhouse. Trays remained in the greenhouse until I observed a consistent lack of emergence for an 8-week period. After this, I removed all seeds that had not emerged from the sand and all seeds with radicles at least $1 \mathrm{~mm}$ long were considered germinated (Fowler and Fowler 1987). Viability of all seeds without emerged radicles was tested using tetrazolium (TZ)(AOSA 2000).

Data Analysis

The proportion of seeds that germinated was determined for each $\mathrm{S}_{\mathrm{tt}}$ unit treatment by dividing the number of germinated seeds by the number of viable seeds. For analyses, the trays were treated as subsamples and percent germination was averaged. To determine whether I could treat the two North treatments and two South treatments as replicates of one another, I first used a generalized linear mixed model with Unit, Stratification and Scarification as effects (PROC GLIMMIX) and a binomial distribution and logistic relationship (SAS v 9.2, SAS Institute, Cary North Carolina, USA). The Unit effect was significant $\left(\mathrm{F}_{1,16}=10.25 \mathrm{p}=0.0056\right)$; therefore, for all subsequent analyses stratification treatments were treated as individual treatments.

Next, I used a generalized linear mixed model (PROC GLIMMIX) with a binary distribution that included Population as a fixed effect and a second model that included Tree as a fixed effect to see if the probability of germination was similar among trees and 
Table C2. Maximum and minimum temperatures and day length for the months of October-May for both the South and North regimes. Day length refers to the length of time lights were on in the growth units. Programmed and mean observed temperatures ( \pm S.E.M) are listed for each month. $S_{\mathrm{tt}}$ unit for each treatment were calculated based upon observed temperatures.

\begin{tabular}{|c|c|c|c|c|c|c|}
\hline Treatment & Month & $\begin{array}{l}\text { Programmed } \\
\text { Max Temp } \\
\left({ }^{\circ} \mathrm{C}\right)\end{array}$ & $\begin{array}{l}\text { Observed } \\
\text { Max Temp } \\
\left({ }^{\circ} \mathrm{C}\right)\end{array}$ & $\begin{array}{l}\text { Programmed } \\
\text { Min Temp } \\
\left({ }^{\circ} \mathrm{C}\right)\end{array}$ & $\begin{array}{l}\text { Observed } \\
\text { Min } \\
\text { Temp } \\
\left({ }^{\circ} \mathrm{C}\right) \\
\end{array}$ & $\begin{array}{l}\text { Day } \\
\text { Length } \\
\text { (hrs) }\end{array}$ \\
\hline \multirow{8}{*}{ North-1138 $\mathrm{S}_{\mathrm{tt}}$} & October & 22.8 & $22.6 \pm 0.088$ & 4.0 & $3.1 \pm$ & 11.1 \\
\hline & November & 15.9 & $15.6 \pm 0.042$ & 0 & $-0.62 \pm$ & 10.2 \\
\hline & December & 10.8 & $10.6 \pm 0.100$ & 0 & $0.13 \pm$ & 9.75 \\
\hline & January & 11.0 & $10.5 \pm 0.200$ & 0 & $0.26 \pm$ & 10 \\
\hline & February & 14.1 & $13.4 \pm 0.147$ & 0 & $0.30 \pm$ & 10.8 \\
\hline & March & 18.0 & $17.7 \pm 0.100$ & 0 & $0.23 \pm$ & 11.8 \\
\hline & April & 22.7 & $22.5 \pm 0.022$ & 2.6 & $1.4 \pm$ & 12.9 \\
\hline & May & 27.6 & $27.4 \pm 0.008$ & 7.5 & $6.0 \pm$ & 13.8 \\
\hline \multirow[t]{8}{*}{ North-1507 $\mathrm{S}_{\mathrm{tt}}$} & October & 22.8 & $23.4 \pm 0.342$ & 4.0 & $4.1 \pm$ & 11.1 \\
\hline & November & 15.9 & $16.7 \pm 0.19$ & 0 & $2.0 \pm$ & 10.2 \\
\hline & December & 10.8 & $12.6 \pm 0.311$ & 0 & $1.2 \pm$ & 9.75 \\
\hline & January & 11.0 & $12.1 \pm 0.257$ & 0 & $2.9 \pm$ & 10 \\
\hline & February & 14.1 & $15.5 \pm 0.186$ & 0 & $2.2 \pm$ & 10.8 \\
\hline & March & 18.0 & $18.5 \pm 0.189$ & 0 & $0.74 \pm$ & 11.8 \\
\hline & April & 22.7 & $21.9 \pm 0.206$ & 2.6 & $2.7 \pm$ & 12.9 \\
\hline & May & 27.6 & $26.5 \pm 0.016$ & 7.5 & $7.7 \pm$ & 13.8 \\
\hline \multirow[t]{8}{*}{ South $-233 \mathrm{~S}_{\mathrm{tt}}$} & October & 29.8 & $30.2 \pm 0.224$ & 12.2 & $12.5 \pm$ & 11.2 \\
\hline & November & 23.9 & $26.6 \pm 0.182$ & 5.6 & $6.3 \pm$ & 10.5 \\
\hline & December & 19.2 & $22.5 \pm 0.118$ & 4 & $4.3 \pm$ & 10.1 \\
\hline & January & 19.5 & $21.9 \pm 0.050$ & 4 & $3.6 \pm$ & 10.3 \\
\hline & February & 22.8 & $23.0 \pm 0.052$ & 4 & $3.3 \pm$ & 11.0 \\
\hline & March & 26.8 & $27.2 \pm 0.038$ & 6.6 & $5.9 \pm$ & 11.8 \\
\hline & April & 31.4 & $31.7 \pm 0.192$ & 11.1 & $10.7 \pm$ & 12.7 \\
\hline & May & 36.8 & $33.0 \pm 0.936$ & 16.4 & $16.5 \pm$ & 13.5 \\
\hline \multirow[t]{8}{*}{ South $-197 \mathrm{~S}_{\mathrm{tt}}$} & October & 29.8 & $28.2 \pm 0.109$ & 12.2 & $11.9 \pm$ & 11.2 \\
\hline & November & 23.9 & $26.6 \pm 0.015$ & 5.6 & $6.1 \pm$ & 10.5 \\
\hline & December & 19.2 & $23.4 \pm 0.230$ & 4 & $4.4 \pm$ & 10.1 \\
\hline & January & 19.5 & $22.9 \pm 0.023$ & 4 & $4.8 \pm$ & 10.3 \\
\hline & February & 22.8 & $23.6 \pm 0.114$ & 4 & $3.8 \pm$ & 11.0 \\
\hline & March & 26.8 & $27.8 \pm 0.024$ & 6.6 & $6.3 \pm$ & 11.8 \\
\hline & April & 31.4 & $32.4 \pm 0.196$ & 11.1 & $10.8 \pm$ & 12.7 \\
\hline & May & 36.8 & $33.7 \pm 0.160$ & 16.4 & $16.5 \pm$ & 13.5 \\
\hline
\end{tabular}


populations. I found that germination rates between populations, within populations and among trees were not significantly different and, therefore, did not include populations or tree as covariates in subsequent analyses. Due to lack of true replication, statistical analyses of treatment effect and differences in treatment means were not carried out. Instead, I had to rely on apparent trends in the data. I used analysis of variance (PROC GLM) with Stratification, Scarification and their interaction as effects to examine the trend in the relationship between germination rate and scarification and stratification treatment.

Germination periods were determined for each treatment as the length of time, in days, from the onset of emergence until the last day of emergence. Additionally, the time until germination was estimated using two metrics. The first metric was a modified Timson index (Timson 1965), germination velocity (GV) (Khan and Ungar 1984)(Appendix A), where the higher the GV value is, the more rapidly germination occurred. The second metric was mean germination time (MGT) in days (Chien et al. 2006) (Appendix A). MGT is a measure of how quickly germination occurred and of the sharpness of the germination peak. A smaller number indicates a faster germination time.

\section{RESULTS}

\section{Probability of germination north and south of and near the range limit}

Overall, a lower proportion of scarified seeds appeared to germinate than nonscarified seeds. However, the effect of scarification varied depending on stratification treatment (Fig. 3). With 192, 233, and $821 \mathrm{~S}_{\mathrm{tt}}$ units, a lower proportion of scarified seeds appeared to germinate, whereas, with $1507 \mathrm{~S}_{\mathrm{tt}}$ units a higher proportion of scarified seeds appeared to germinate. The relationship between the proportion of seeds that germinated 
and $\mathrm{S}_{\mathrm{tt}}$ units appeared to be quadratic. Germination increased with $\mathrm{S}_{\mathrm{tt}}$ units until approximately $1020 \mathrm{~S}_{\mathrm{tt}}$ units after which the probability of germination declined.

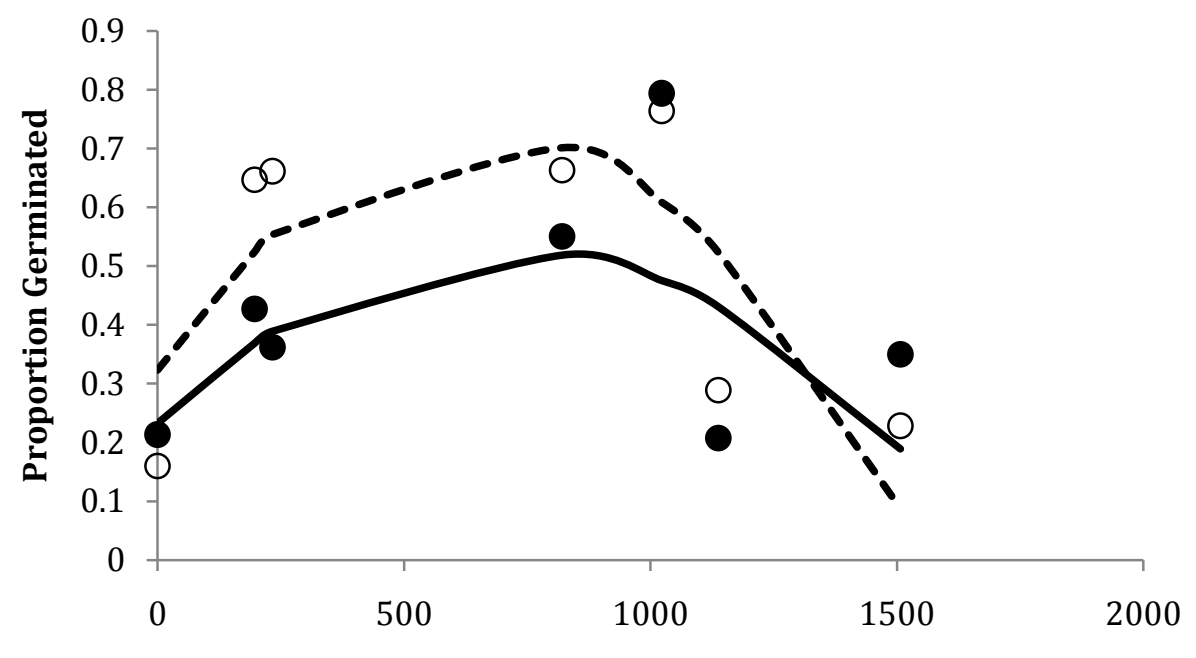

Stratification Thermal Time Units

Figure C1. Proportion of Russian olive seeds germinated as of function of stratification thermal time units. Open circles denote non-scarified seeds and closed circles denote scarified seeds. The dashed line represents non-scarified values predicted by the model: $y=0.3328-0.0000009 x^{2}+0.0012 x$. The black line represent scarified values predicted by the model: $y=0.2326-0.00000055 x^{2}+0.0008 x$.

Germination time north and south of and near the range limit

The germination period was longest for the South treatments, followed by the Control, the Intermediate treatments and finally the North treatments. The North and Intermediate treatments had very similar germination periods. There was not a consistent trend in length of germination period and scarification treatment (Table C3). Mean germination time (MGT) and germination velocity (GV) values both indicate that germination was most rapid in the Intermediate treatments, followed by the South treatments, the North treatments and the Control (Table C3). 


\section{DISCUSSION}

I found that ideal stratification conditions for Russian olive seeds appear to exist at latitudes ranging from $31.65-32.30^{\circ} \mathrm{N}$ near the southern range limit. I observed a quadratic relationship between stratification thermal time units $\left(S_{\mathrm{tt}}\right.$ units $)$ and

Table C3. Stratification Treatment and Germination Time Two metrics are included Mean Germination Time (MGT) and Germination Velocity (GV). The smaller the MGT value the faster the germination. The larger the $\mathrm{GV}$ value the faster the germination. $\mathrm{C}$ denotes Control, I denotes Intermediate, $\mathrm{N}$ denotes North and $\mathrm{S}$ denotes South.

\begin{tabular}{llllll}
\hline Treatment & \multicolumn{2}{c}{ Germination Time } & \multicolumn{3}{c}{ Germination Period } \\
& MGT(days) & GV & Scarified & $\begin{array}{l}\text { Non- } \\
\text { Scarified }\end{array}$ & Average \\
\hline C-0 & 123 & 0.6548 & 156 & 203 & 180 \\
S-197 & 175 & 2.7020 & 226 & 224 & 225 \\
S-233 & 154 & 2.4514 & 210 & 224 & 217 \\
I-821 & 66 & 3.8114 & 80 & 105 & 93 \\
I-1023 & 46 & 6.1590 & 105 & 66 & 86 \\
N-1138 & 69 & 0.9715 & 140 & 31 & 86 \\
N-1507 & 80 & 0.9054 & 76 & 76 & 76 \\
\hline
\end{tabular}

germination, with the highest germination occurring with $\mathrm{S}_{\mathrm{tt}}$ units representative of locations near the southern range limit, lower germination with $\mathrm{S}_{\mathrm{tt}}$ units representative of locations far south of the southern range limit, and the lowest germination for $\mathrm{S}_{\mathrm{tt}}$ units representative of locations north of the southern range limit. This pattern only weakly supports the hypothesis that germination would decrease south of the southern range limit. Although germination declined with decreasing $\mathrm{S}_{\mathrm{tt}}$ units south of the southern range limit, it declined to levels within the range observed by Hogue and LaCroix (1970) under ideal germination conditions.

Several factors may have contributed to the decline in germination above $1020 \mathrm{~S}_{\mathrm{tt}}$ units. The North treatments received less warm incubation time to overcome dormancy because these treatments were cooler. Additionally, studies have found that cold 
stratification extending beyond the ideal length can induce secondary dormancy in nondormant seeds (Kebreab and Murdoch 1999, Bouwmeester and Karssen 1992, Staniforth and Cavers 1979). My North treatments received 1138-1507 $\mathrm{S}_{\mathrm{tt}}$ units, substantially more than the ideal germination range found by Hogue and LaCroix (1970; 800-900 $\mathrm{S}_{\mathrm{tt}}$ units). Finally, non-dormant seeds can reenter dormancy if seeds experience inappropriate germination conditions (Bonner 2008, Hilhorst 1998, Kebreab and Murdoch 1999), such as extreme temperatures at crucial times (McLemore 1966, Mumford 1988). Mumford (1988) found that if a cold stratification period was interrupted by a short period of warm temperatures before the stratification requirement had been met, secondary dormancy was induced in Impatiens glandulifera. Mid-experiment, the North growth units malfunctioned for a 5 day period and had a mean temperature of $\sim 25^{\circ} \mathrm{C}$, after which they were returned to their respective regimes of cold stratification; this could have induced secondary dormancy. If the length of the experiment had been longer and the North growth units had not malfunctioned, it is likely that germination rates would have been higher in the North treatments. My results speak to both the complexity of factors that inhibit or promote dormancy and the difficulty in realistically simulating environmental parameters in an experimental setting.

In addition to final percent germination, the germination time can also indicate favorable stratification temperatures. Germination time was fastest in the Intermediate treatments (most rapid in Intermediate-1023). This finding, paired with high germination in the Intermediate treatments, indicates that the ideal range of $\mathrm{S}_{\mathrm{tt}}$ units occurs at or near the southern range limit. Scarification could also increase germination time by causing a 
more rapid response to warm incubation; however, this apparently did not occur in my experiments.

I found that scarification had a negative effect on the proportion of seeds that germinated. This is the opposite of what I would expect ecologically because scarification generally increases the permeability of the seed coat to water and oxygen (Bonner 2008). If this occurs, I would expect that scarification would increase germination where stratification was limited (e.g., in the Control and South treatments). My results did not consistently support this hypothesis. Scarification did increase germination of the Control as expected, but the scarified South treatments had lower germination rates than non-scarified South treatments. One explanation for my counterintuitive results is that the scarification treatment ruined the integrity of the seeds. If this were the case, I would expect there to be more non-viable seeds in the scarified treatments. I did not find support for this in the scarified treatments overall or within any of the temperature treatments. However, another plausible explanation is that scarification caused injury to the seeds and induced secondary dormancy (Bonner 2008), leading to lower germination rates.

There is a tremendous range in the degree of dormancy in woody species, both between species and among species (Bonner 2008). The timing of germination can also vary greatly even among a group of seeds from the same population (McLemore and Barnett 1966, Rink et al. 1979). Because of this, stratified seeds often emerge more uniformly. The low temperatures of cold stratification limit germination of non-dormant seeds, while dormant seeds undergo the necessary internal changes required for germination. When the seeds are finally exposed to favorable conditions, they germinate 
and emerge in a narrow temporal window (Bonner 2008). The intermediate and north treatments had the shortest germination periods ( 80 and 81 days, respectively) compared to the Control and South treatments (168 and 221 days, respectively). The seeds in the South treatment received very few $\mathrm{S}_{\mathrm{tt}}$ units; therefore, the seeds that germinated had little or no dormancy. The broad germination period in the South treatments is consistent with a pattern observed in other species (Bouwmeester and Karssen 1992, Schütz et al. 2002); when seeds are relieved of dormancy, they are characterized by a widening of the range of temperatures over which germination can proceed.

Because my treatments mimicked natural temperature regimes, I gained insight into the emergence patterns that may occur in nature, as I could not find the natural timing of germination in the published literature. Based upon the length of germination periods observed for each treatment, near the range limit and north of the range limit seedlings are likely to emerge uniformly, whereas south of the range limit, emergence is likely to be more sporadic and uneven. Near the range limit the flush of emergence is likely to occur from February through early April; whereas, in the south it is likely to occur from November through May. Although temperatures are mild far south of the range limit, there are still approximately 75 frost days each year in the Chihuahuan Desert of Mexico (Schmidt 1986), and seedlings could be susceptible to frost if they germinate early or to drought if they germinate late. 
APPENDIX D. PRELIMINARY BUD-BREAK EXPERIMENT, 2009-2010.

\section{METHODS}

Cuttings were taken on January $28^{\text {th }} 2009$ from 20 Socorro saplings and 20 Fort Collins adults. One branch from each tree was cut into five pieces that each had a minimum of 3 buds and a maximum of 5 buds. The basal end of each cutting was then put in water in a refrigerator held at $6^{\circ} \mathrm{C}$ where they received: 19 additional days of chilling, 27 additional days of chilling, or 34 additional days of chilling. When the additional chilling had been received, cuttings were moved to a greenhouse with an average daytime temperature of $23.9^{\circ} \mathrm{C}$, average nighttime temperature of $18.5^{\circ} \mathrm{C}$ and a 16-hour photoperiod with supplemental light from HID 430 watt lights for forcing. A Control treatment received no additional chilling and was placed in the greenhouse at the beginning of the experiment.

Chilling treatments can also be expressed in terms of chill units using the methods of Linvill (1990) (Appendix A). At the time cuttings were taken, buds on the Socorro saplings had received 735 Chill Units (CU's) and Fort Collins Adults had received 719 CU's. Therefore, the treatment with 19 additional days accumulated $1131 \mathrm{CU}$ 's for Saplings and 1147 CU's for Adults. The treatment with 27 additional days accumulated 1311 CU's for Saplings and 1327 CU's for Adults. Finally, the treatment with 34 additional days accumulated 1447 CU's for Saplings and 1467 CU's for Adults. 


\section{RESULTS}

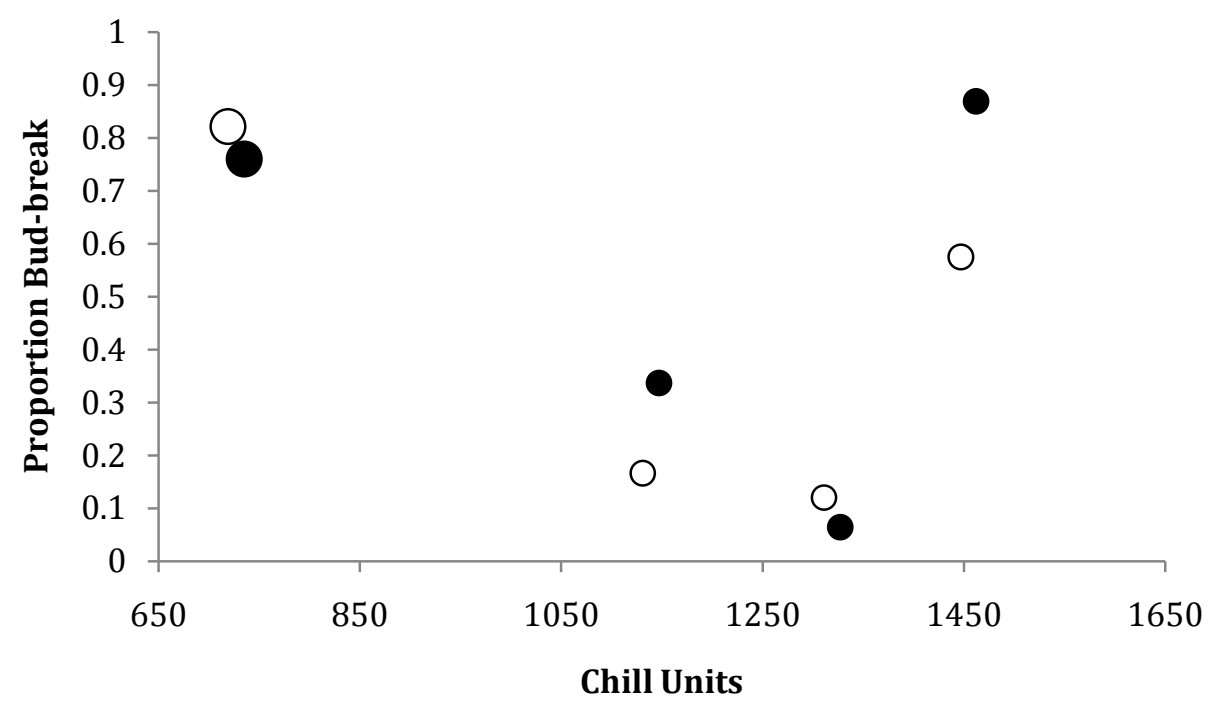

Figure D1. Proportion Russian olive bud-break as a function of Chill Units (Linvill 1990). Open circles denote Saplings and closed circles denote Adults. Large circles denote treatments that received all chilling naturally. Small circles denote treatments where additional chilling was received in a refrigerator held at $6^{\circ} \mathrm{C}$.

\section{DISCUSSION}

I observed high bud-break with 719-735 Chill Units. Bud-break proportion was similar to those observed for whole saplings in the bud-break experiment described in the main body of thesis $(\sim 80-85 \%)$. However, the bud-break proportion in this experiment was much higher than that observed for adult and sapling cuttings ( $\sim 35$ and $25 \%$, respectively) in the previous bud-break experiment. However, these results should be interpreted with caution because the act of cutting up the twigs into multiple pieces may have affected hormone balance, and thus chilling requirement. Finally, these results indicate that the act of putting the cuttings in the refrigerator may have induced secondary dormancy of the buds. It looks like approximately 700 more chill units were required to break this dormancy. These results indicate that any experiment where chill units are not accumulated naturally should begin before the onset of chill unit accumulation. 


\section{APPENDIX E: VEGETATIVE AND FLOWERING GROWTH AND FRUIT DEVELOPMENT OF ADULT RUSSIAN OLIVE TREES.}

\section{METHODS}

\section{Data collection}

In the spring of 2009, I monitored flower and fruit development of sexually mature adults trees $(n=10)$ in Fort Collins, CO. Data were collected after the peak of flowering (anthesis approximately two weeks). Data were collected on a subsample of four branches per tree $(\mathrm{n}=40$ mean node diameter $=17.87 \mathrm{~cm}$, range $11.9-24.8 \mathrm{~cm})$. These data comprised a subsample that I hoped was representative of the entire tree. Sampled branches had a diameter of 1-2 cm where attached to the main trunk and had "segments" and "twigs" branching off of it. Sampled branches were all $<3.5 \mathrm{~m}$ above ground. The term "twig" was used to denote the current year's growth, and "segment" was used to denote a section of $1+$ year old growth (Fig. E1).

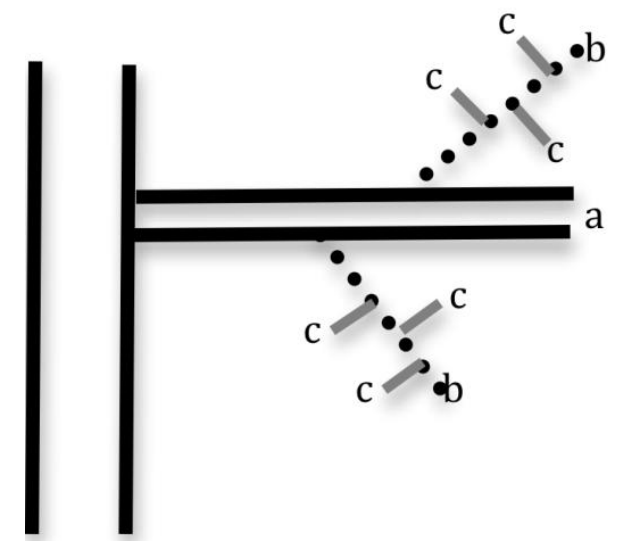

Figure E1: Schematic of Russian olive tree. Solid black lines marked a denote a main branch, dashed black lines marked $\mathrm{b}$ denote a segment and solid gray lines marked $\mathrm{c}$ denote a twig. A main branch has its first node on the main trunk or very close to the main trunk. A segment branches off a main branch and is a section of 1+ year old growth. A twig branches off of a segment and is the current year's growth. 
Leaves are alternate in small lateral clusters on twigs of the current year and flowers are in axillary clusters on the twigs of the current year. I noted both vegetative and flowering segment lengths for four main branches per tree. I began measuring the length of the vegetative segments from the first active vegetative bud on the segment to the first active flowering bud. Likewise, I began measuring flowering segments from the first active flowering bud to the end of the segment. I also noted the length on the main branch from the first node to the first vegetative growth. I added this node-to-vegetative growth value to the sum of the flowering and vegetative segment lengths for total branch length.

\section{Data Analysis}

Twigs were categorized as either vegetative or flowering. The total number of flowering twigs was then divided by12 and that interval was used to systematically choose 12 twigs along the length of each branch for reproductive data collection. Potential flowering on a twig was calculated as the total of buds, scars, stems with ovaries, and flowers. Any stem with an ovary developing was also counted as a developing fruit. The total number of flowering twigs was multiplied by the average value of the 12 twigs for both potential flowering and developing fruit for a total potential flowering value and developing fruit value per branch. The proportion of flowering twigs per branch was calculated by dividing the number of flowering twigs by the total number of twigs. The proportion flowering length per branch was calculated by dividing the flowering length by total branch length and the proportion vegetative length was calculated by dividing the vegetative length by total branch length. Flowering potential per $\mathrm{cm}$ and developing fruit per $\mathrm{cm}$ were both calculated for each branch by dividing total 
values by flowering length $(\mathrm{cm})$. Finally, for each branch, the proportion of potential flowers developing into fruit was calculated by dividing the developing fruit value by the total flowering potential value. The four branch values of each tree were then averaged for a tree average. I had hoped to also monitor initial fruit crop, final fruit crop, and the percentage of twigs on each branch that had formed a terminal bud. However, a large hailstorm severely damaged the fruit crop of these trees. 


\section{RESULTS}

Table E1. Flowering potential and fruit development of sexually mature Russian olive trees $(\mathrm{n}=10)$ in Fort Collins, CO in June 2009. Tree means are presented as well as a population mean \pm standard error of the mean. Mean proportion developing fruit refers to the mean proportion of potential flowers developing into fruit.

\begin{tabular}{|c|c|c|c|c|c|c|}
\hline Tree \# & $\begin{array}{l}\text { Mean } \\
\text { proportion } \\
\text { flowering } \\
\text { twigs }\end{array}$ & $\begin{array}{l}\text { Mean } \\
\text { proportion } \\
\text { flowering } \\
\text { length }\end{array}$ & $\begin{array}{l}\text { Mean } \\
\text { proportion } \\
\text { vegetative } \\
\text { length }\end{array}$ & $\begin{array}{l}\text { Mean } \\
\text { flowering } \\
\text { potential per } \\
\mathrm{cm}\end{array}$ & $\begin{array}{l}\text { Mean } \\
\text { developing } \\
\text { fruits per cm }\end{array}$ & $\begin{array}{l}\text { Mean } \\
\text { proportion } \\
\text { developing } \\
\text { fruit }\end{array}$ \\
\hline 1 & 0.83 & 0.73 & 0.20 & 10.05 & 3.47 & 0.35 \\
\hline 2 & 0.71 & 0.72 & 0.23 & 6.54 & 2.23 & 0.32 \\
\hline 3 & 0.75 & 0.72 & 0.26 & 8.47 & 1.10 & 0.13 \\
\hline 4 & 0.73 & 0.53 & 0.42 & 9.36 & 1.67 & 0.18 \\
\hline 5 & 0.69 & 0.56 & 0.40 & 7.27 & 1.88 & 0.26 \\
\hline 6 & 0.51 & 0.43 & 0.55 & 7.98 & 1.39 & 0.18 \\
\hline 7 & 0.56 & 0.54 & 0.41 & 7.78 & 0.63 & 0.08 \\
\hline 8 & 0.43 & 0.35 & 0.57 & 7.57 & 1.28 & 0.16 \\
\hline 9 & 0.25 & 0.29 & 0.62 & 4.69 & 0.44 & 0.10 \\
\hline 10 & 0.39 & 0.36 & 0.59 & 5.15 & 0.72 & 0.14 \\
\hline $\begin{array}{l}\text { Pop } \\
\text { Mean }\end{array}$ & $0.52 \pm 0.01$ & $0.58 \pm 0.05$ & $0.42 \pm 0.05$ & $7.49 \pm 0.53$ & $1 \pm 0.28$ & $0.19 \pm 0.03$ \\
\hline
\end{tabular}




\section{APPENDIX F: FRUIT PRODUCTION AND SEED VIABILITY ALONG A LATITUDINAL GRADIENT.}

\section{METHODS}

\section{Data collection}

In early fall 2009; I carried out general fruit set surveys on naturalized Russian olive populations along three riparian corridors (Rio Grande near Las Cruces, NM $32.31^{\circ} \mathrm{N}, 106.77^{\circ} \mathrm{W}$, Range-Limit latitude; Rio Grande near Socorro, NM $34.07^{\circ} \mathrm{N}$ $106.90^{\circ} \mathrm{W}$, Intermediate-Latitude; and Big Thompson River near Loveland, $\mathrm{CO} 40.45^{\circ} \mathrm{N}$, $105.07^{\circ} \mathrm{W}$, North-latitude). The three locations were representative of a north to south gradient terminating at Russian olive's southern range limit. $40.45^{\circ} \mathrm{N}$ (North-latitude) represented a location far north of the southern range limit, $34.07^{\circ} \mathrm{N}$ (Intermediatelatitude) represented an intermediate location north of the southern range limit, and $32.31^{\circ} \mathrm{N}$ (Range-Limit-latitude) represented a location at the southern range limit. At the Intermediate-latitude and North-latitude, where stands of Russian olive trees were more common, I collected fruit set data from multiple sites to average out local variability. I surveyed five trees at each of three sites that were at least $500 \mathrm{~m}$ apart (15 trees total). At the Range-Limit-latitude, where only one stand of naturalized Russian olive trees was found along the river channel, I collected fruit set data from 15 trees at one site.

On each tree I randomly selected four main branches (one in each cardinal direction) and three random segments of $1+$ year growth $(n=12$ segments per tree) (Singh 
and Kushwaha 2006). For each segment, I measured the length (excluding the basal portion without leaves) and collected fruit to be counted later in the lab. The number of fruits per segment was divided by segment length and the fruits per centimeter values for all segments were averaged for each tree. I also recorded the diameter at breast height diameter (dbh) of each tree. If the tree was multi-stemmed, I recorded the dbh of each individual stem and summed these values for a total dbh value.

At the trees used for the fruit production surveys described above, I concurrently collected fruit for viability testing. Fruit were hand cleaned until only the seed remained and 15 seeds from each tree were Tetrazolium (TZ)-tested for viability (AOSA 2000).

\section{Data analysis}

I first carried out a simple regression to examine whether tree size (dbh) was related to fruit set. Because dbh was not correlated with fruit set $\left(R^{2}: 0.003 ; p=0.996\right)$, I did not include dbh as a covariate in subsequent models. I observed in the field that trees with larger fruit might have produced fewer fruit per centimeter; if there were more trees with larger fruit at the lowest latitude this could bias my data. To correct for this, I calculated weighted fruit per centimeter values per tree. Seed mass was strongly correlated with seed diameter $\left(\mathrm{R}^{2}: 0.73, \mathrm{n}=120\right.$ seeds); therefore I used seed mass as a proxy for fruit size. I took the mass of nine sets of 10 seeds from all trees used in the experiment. For each tree I averaged these nine values for a mean seed mass, which I used as a weighting factor. For each location I then calculated a weighted mean fruit per centimeter value. Weighted and non-weighted values were not different in rank; therefore, I used the non-weighted value in subsequent analysis. I then used a mixed effect linear model (PROC MIXED) with Latitude as a fixed effect, and Site, Latitude 
and Tree as random effects to examine the relationship between latitude and fruit set (fruits/cm). Site was nested within Latitude and Tree was nested within Site. I used least squared means for mean separation (at the $\mathrm{p}<0.05$ level).

The proportion of viable seeds per tree was determined by dividing the number of viable seeds by the total number of seeds tested. The proportion of viable seeds value was then averaged across trees in a population for a mean proportion viable value for each population, which corresponded to particular latitude. I used a generalized linear mixed model (PROC GLIMMIX) with a binomial distribution and logistic relationship and included Latitude as a fixed effect and Latitude and Site as random effects (Site nested within Latitude) to analyze the relationship between latitude and the proportion of viable seeds. I used least squared means for mean separation (at the $\mathrm{p}<0.05$ level).

\section{RESULTS}

Although mean fruit per cm decreased with decreasing latitude from 2.063 fruit per $\mathrm{cm}$ at $40.59^{\circ} \mathrm{N}$ (North-latitude), to 1.490 fruit per $\mathrm{cm}$ at the $34.05^{\circ} \mathrm{N}$ (Intermediatelatitude) and finally, to 1.475 fruit per $\mathrm{cm}$ at $32.30^{\circ} \mathrm{N}$ latitude (Range-Limit-latitude), the effect of latitude was not statistically significant $\left(\mathrm{F}_{2,4}=2.96, \mathrm{p}=0.1626\right)$.

Latitude had a positive relationship with the proportion of viable seeds $\left(\mathrm{F}_{2,4}=9.79\right.$, $\mathrm{p}=0.03$ ) and the proportion of viable seeds decreased with decreasing latitude from 0.804 at $40.59^{\circ} \mathrm{N}$ (North-latitude) to 0.662 at $34.05^{\circ} \mathrm{N}$ (Intermediate-latitude) and to 0.618 at $32.30^{\circ} \mathrm{N}$ (Range-Limit-latitude). The North-latitude had a greater proportion of viable seeds than both the Intermediate-latitude $\left(34.06^{\circ} \mathrm{N}\right)$ and the Range-Limit-latitude $(\mathrm{p}=0.028 ; \mathrm{p}=<0.013$, respectively). However, the Range-Limit-latitude did not have a lower proportion of viable seeds than the Intermediate-latitude $(\mathrm{p}=0.382)$. 


\section{DISCUSSION}

Fruit production was not different among locations. This is consistent with many other studies that have found sexual reproduction at range limits (Tremblay et al. 2002, Desponts and Payete 1992, Meilleur et al. 1997). Viability, however, was different among locations and declined towards the southern range limit. However, the proportion of viable seeds was similar north of and near the range limit. There has been limited support for declined fitness toward the edge of range limits (see meta-analysis in Sexton et al. 2009). Latitude is correlated with many climate variables that I did not measure and; therefore, I do not know the exact mechanism explaining the trend in my data. My results indicate that reproductive output (fruit set and viability) could be one of the limiting factors, but not the sole factor limiting the distribution of Russian olive. My data indicate one weakness in documenting trends in fitness across the landscape; I could only locate and access one natural riparian stand of Russian olive trees near the range limit. Favorable habitat was limited, but the trees I measured may have been in a patch of favorable habitat and thus had high fitness (Sexton et al. 2009). Additionally, I only had one year of data and therefore did not capture potential inter-annual variability in climate and fitness. 


\section{REFERENCES}

Association of Official Seed Analysis (AOSA) (2000) Tetrazolium testing handbook. In: Contribution No. 29. Handbook on seed testing. pp 302 AOSA, Lincoln, NE.

Bonner FT (2008) Seed Biology In: Bonner FT, Karrfalt RP (eds) The woody plant seed manual agricultural handbook 727 pp 4-32.

Bouwmeester HJ, Karssen CM (1992) The dual role of temperature in the regulation of the seasonal changes in dormancy and germination of seeds of Polygonum persicaria L. Oecologia 90: 88-94.

Chien CT, Chen SY, Chang SH, Chung JD (2006) Dormancy and germination in seeds of the medicinal Asian tree species Phellodendron amurense var. wilsonii (Rutaceae). Seed Sci and Technol 34: 561-571.

Desponts M, Payette S (1992) Recent dynamics of Jack Pine at its northern distribution limit in Northern Quebec. Can J Bot 70: 1157-1167.

Handley RJ, Davy AJ (2005) Temperature effects on seed maturity and dormancy cycles in an aquatic annual, Najas marina, at the edge of its range. J Ecol 93: 1185-1193.

Heit CE (1967) Propogation from seed: 6 . Hard-seededness - a critical factor. Am Nurseryman 125: 10-12, 88-96.

Hilhorst HWM (1998) The regulation of secondary dormancy. The membrane hypothesis revisted. Seed Sci Res 8: 77-90.

Hogue, EJ, LaCroix LJ (1970) Seed dormancy of Russian olive (Elaeagnus angustifolia L.) J Am Soc for Hortic Sci 95: 449-452.

Hoehler FK (1995) Logistic equations in the analysis of s-shaped curves. Comput Biol Med 25: 367-371.

Khan MA, Ungar IA (1984) The effect of salinity and temperature on the germination of polymorphic seeds and growth of Atriplex triangularis Willd. Am J Bot 71: 481489.

Kebreab E, Murdoch AJ (1999) A quantitative model for loss of primary dormancy and induction of secondary dormancy in imbibed seeds of Orobanches spp. J Exp Bot 50: 211-219.

Linvill DE (1990) Calculating chilling hours and chill units from daily maximum and minimum temperature observations. HortScience 25: 14-16.

McLemore BF (1966) Temperature effects on dormancy and germination of Loblolly Pine seed. Forest Sci 12 : 284-289.

Meilleur A, Brisson, J, Bouchard A (1997) Ecological analyses of the northernmost population of pitch pine (Pinus rigida). Can J Forest Res 27: 1342-1350.

Mumford PM (1988) Alleviation and induction of dormancy by temperature in Impatiens glandulifera Royle. New Phytol 109:107-110.

Rink G, Dell TR, Switzer G, Bonner FT (1979) Use of the Weibull function to quantify sIetgum germination data. Silvae Genet 28: 9-12.

Singh KP, Kushwaha CP (2006) Diversity of flowering and fruiting phenology of trees in a tropical deciduous forest in India. Ann Bot 97: 265-276.

Schmidt RH Jr (1986) Chihuahuan climate. In: Barlow JC, Powell MA, Timmermann BN (eds.) Procedings of the Second Symposium on the Resources of the Chihuahuan Desert Region, Chihuahuan Desert Research Institute, October 20-21 Alpine, Texas pp 40-63.

Schütz W, Milberg P, Lamont BB (2002) Seed dormancy, after-ripening and light 
requirement of four annual Asteraceae in South-western Australia. Ann Bot 90:707-714.

Sexton JP, McIntyre PJ, Angert AL, Rice KJ (2009) Evolution and ecology of species range limits. Annu Rev of Ecol Evol Syst 40: 415-436.

Staniforth R, Cavers P (1979). Field and laboratory germination response of achenes of Polygnum lapathifolium, P. penslvanicum and P. persicaria. Can J Bot 57: 877885.

Timson J (1965). New method of recording germination data. Nature 207: 216-217.

Tremblay MF, Bergeron Y, Lalonde D, Mauffette Y (2002) The potential effects of sexual reproduction and seedling recruitment on the maintenance of red maple Acer rubrum L.) populations at the northern limit of the species range. J Biogeogr 29: $365-373$. 